\title{
Sulindac Sulfide, an Aspirin-like Compound, Inhibits Proliferation, Causes Cell Cycle Quiescence, and Induces Apoptosis in HT-29 Colon Adenocarcinoma Cells
}

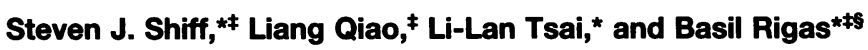 \\ *The Rockefeller University Hospital, Laboratory of Human Behavior and Metabolism, New York 10021; and Cornell University \\ Medical College, Departments of ${ }^{\ddagger}$ Medicine and ${ }^{8}$ Microbiology, New York 10021
}

\begin{abstract}
Nonsteroidal antiinflammatory drugs (NSAIDs), have cancer preventive and tumor regressive effects in the human colon. They lower the incidence of and mortality from colorectal cancer and sulindac reduces the number and size of polyps in patients with familial adenomatous polyposis.

We studied the effect of sulindac, and its metabolite sulindac sulfide, on the proliferation of HT-29 colon adenocarcinoma cells. Both compounds reduced the proliferation rate of these cells, changed their morphology, and caused them to accumulate in the $G_{0} / G_{1}$ phase of the cell cycle. These responses were time- and concentration-dependent and reversible. In addition, these compounds reduced the level and activity of several cyclin-dependent kinases (cdks), which regulate cell cycle progression. Sulindac and sulindac sulfide also induced apoptosis in these cells at concentrations that affected their proliferation, morphology, and cell cycle phase distribution. Sulindac sulfide was approximately sixfold more potent than sulindac in inducing these cellular responses.
\end{abstract}

Our results indicate that inhibition of cell cycle progression and induction of apoptotic cell death contribute to the anti-proliferative effects of sulindac and sulindac sulfide in HT-29 cells. These findings may be relevant to the cancer preventive and tumor regressive effects of these compounds in humans. (J. Clin. Invest. 1995. 96:491-503.) Key words: sulindac • apoptosis $\bullet$ cyclin-dependent kinases • colon cancer $\cdot$ proliferation

\section{Introduction}

Nonsteroidal antiinflammatory drugs (NSAIDs) ${ }^{1}$ are among the most commonly used medications. Their use dates back to 1875 when sodium salicylate was given to patients with rheumatic fever as an anti-pyretic (1). They are currently utilized in a

Address correspondence to Basil Rigas, M.D., Ph.D., Cornell University Medical College, 1300 York Ave., New York, NY 10021. Phone: 212746-4406; FAX: 212-746-8630.

Received for publication 24 October 1994 and accepted in revised form 30 March 1995.

1. Abbreviations used in this paper: cdks, cyclin-dependent kinases; FAP, familial adenomatous polyposis; NSAIDs, nonsteroidal antiinflammatory drugs.

J. Clin. Invest.

(c) The American Society for Clinical Investigation, Inc.

$0021-9738 / 95 / 07 / 0491 / 13 \$ 2.00$

Volume 96, July 1995, 491-503 variety of clinical situations and are often administered for long periods of time, in certain cases for many years. Indications requiring such long-term use include the prevention of myocardial infarction and cerebrovascular disease and the treatment of chronic inflammatory diseases such as rheumatoid arthritis.

Several epidemiological studies have demonstrated an association between the long-term consumption of NSAIDs and a reduced incidence of and mortality from colon cancer (e.g., most recently, $[2,3])$. Sulindac $\left(\right.$ Clinoril $\left.^{\circledR}\right)$ hás been shown to reduce the number and size of colonic and rectal adenomatous polyps in patients with familial adenomatous polyposis (FAP) $(4,5)$, although this effect may not be permanent $(6)$. In addition, animal studies have shown that NSAIDs have anti-neoplastic effects in the colon. Aspirin (7), sulindac (8), piroxicam (9), and indomethacin (10) all reduce the number and size of tumors arising in the colon of rodents administered colonic carcinogens such as dimethyl-hydrazine or azoxymethane.

Because sulindac has such a marked anti-tumor effect, regressing established adenomatous polyps in patients with FAP, it is important to understand the mechanisms mediating this phenomenon. These theoretically could include the regulation of the dynamics of cell proliferation in the colonic mucosa. This hypothesis is supported by the work of Bayer et al. $(11,12)$, who demonstrated that indomethacin reversibly inhibits the proliferation of human fibroblasts and rat hepatoma cells and arrests them in the $G_{1}$ phase of the cell cycle.

Over the past several years, some of the molecular events governing progression through the various phases of the eukaryotic cell division cycle have been elucidated. Two families of proteins have been shown to play a central role in regulating the major transition points of the cell cycle in all eukaryotic organisms: the cyclins and the cyclin dependent kinases (cdks), (see references 13 and 14 for recent reviews). The cyclins comprise a group of regulatory proteins that share stretches of amino acid sequence homology. The cdks are a family of serine/ threonine protein kinase subunits that associate with cyclins before their activation in discrete phases of the cell cycle (13, 14). All cdks share amino acid sequence homology with $\mathrm{p} 34^{\mathrm{cdc} 2}$, the prototypical molecule of this family. Recently, another family of proteins that play a key role in cell cycle regulation, the cyclin-dependent kinase inhibitors, have been described which interact with cdks or cyclin-cdk complexes to inhibit cdk catalytic activity (15).

The cdks that participate in regulating cell cycle progression include: $(a) \mathrm{p} 34^{\text {cdc2 }}$ which, in concert with the A- and B-type cyclins, controls the $\mathrm{G}_{2} / \mathrm{M}$ transition $(16-19) ;(b) \mathrm{p} 33^{\mathrm{cdk} 2}$, which regulates the $G_{1} / S$ transition $(16,18,20)$ in association with cyclin $\mathrm{E}(21-24)$; and $(c) \mathrm{p} 34^{\text {cdk4 }}(25,26)$ and $\mathrm{p} 40^{\text {cdk6 }}$ (27) which, in conjunction with the D-type cyclins (D1, D2, or D3), control progression through $\mathrm{G}_{1}(28)$. In most proliferating cells, the steady state levels of the cdks do not change apprecia- 
bly throughout the cell cycle $(29,30)$. Thus cdk activity, and therefore advancement through the cell cycle, is regulated in part by the distinctive periodic expression patterns of the different cyclins.

Since indomethacin has been shown to reduce the proliferation and alter the cell cycle of noncolonic cells $(11,12,31)$, it is conceivable that NSAIDs affect colonic epithelial cells in a similar fashion. Therefore, we studied the effect of sulindac and sulindac sulfide, clinically important compounds in the chemoprevention of colon cancer, on the proliferation and the cell cycle of HT-29 colon adenocarcinoma cells.

As sulindac sulfide is considered the active metabolite of sulindac, we elected to use concentrations of sulindac sulfide that could conceivably be achieved in the colon in vivo. A large fraction of sulindac is converted to sulindac sulfide in the colon by colonic bacteria (32). Therefore, high lumenal concentrations of sulindac sulfide are achieved in the colon (33). In addition, animal studies have shown that sulindac sulfide is concentrated in the mucosa of the colon at levels several-fold higher than in the serum (34). Colonic epithelial cells can be exposed to concentrations up to 20-fold higher than those in serum (33); serum levels of sulindac sulfide are about 10-15 $\mu \mathrm{M}$ when sulindac is given orally at doses which regress polyps in FAP patients $(35,36)$. Sulindac, was used at concentrations several times higher than sulindac sulfide to see if the parent compound could mimic its effects.

It is also possible that the mechanisms responsible for the anti-proliferative effects of the NSAIDs on cultured cells is multifactorial. Apoptotic cell death is another mechanism that could contribute to reduced cell growth. Apoptosis has been the focus of intense scrutiny and has become better understood at the molecular genetic level (for recent reviews see references $37-39$ ). It is a genetically determined and evolutionarily conserved process that occurs in a variety of physiological and pathophysiological contexts including: $(a)$ the elimination of self-reactive immune cells; $(b)$ embryonic tissue development; and $(c)$ tumorigenesis. Therefore, we also examined whether these compounds caused apoptosis in HT-29 colon cancer cells.

\section{Methods}

Cell lines. The human colon adenocarcinoma cell line HT-29 (ATCC HTB 38) and the promyelocytic leukemia cell line HL-60 (ATCC CCL 240) were obtained from the American Type Culture Collection (ATCC, Rockville, MD). Culture medium consisted of McCoy's 5A (Cellgro ${ }^{\circledR}$; Mediatech, Inc., Herndon, VA) supplemented with 10\% FBS (Gemini Bioproducts, Inc., Calabasas, CA) for HT-29 cells, and RPMI 1640 $\left(\right.$ Cellgro ${ }^{\circledR}$ ) supplemented with $10 \%$ heat-inactivated FBS for HL-60 cells. In addition, both types of culture media were supplemented with nonessential amino acids, penicillin $(50 \mathrm{U} / \mathrm{ml})$, and streptomycin $(50$ $\mu \mathrm{g} / \mathrm{ml}$ ) (all from GIBCO BRL, Gaithersburg, MD). HT-29 cells were grown as monolayers in 100 - or $150-\mathrm{cm}^{2}$ plates and HL-60 cells were grown in suspension in $100-\mathrm{cm}^{2}$ plates. Both were incubated at $37^{\circ} \mathrm{C}$, in $5 \% \mathrm{CO}_{2}$ and $90 \%$ relative humidity. Cell morphology was recorded daily. To document morphologic alterations, cells grown for $72 \mathrm{~h}$ with or without supplemental sulindac or sulindac sulfide were photographed in the culture dishes using an inverted microscope (Diaphot-TMD; Nikon Inc., Melville, NY). Only areas representative of the morphology of the cells throughout the entire dish were photographed.

Reagents. Sulindac (Sigma Chemical Co., St. Louis, MO) was dissolved in $1 \mathrm{M}$ Tris- $\mathrm{HCl}, \mathrm{pH} 7.5$; the final $\mathrm{pH}$ was adjusted to 7.2 with $10 \mathrm{~N} \mathrm{NaOH}$. Sulindac sulfide (desoxy-sulindac, generously provided by Merck and Co., Rahway, NJ), was dissolved in DMSO (Fisher Scientific, Fair Lawn, NJ). All compounds were added to the culture medium and cells prior to plating them. The DMSO concentration was adjusted to $0.6 \%$ in all sulindac sulfide-supplemented media. Different batches of sulindac sulfide required slightly different final concentrations (within a narrow range) to induce similar effects on the HT-29 cells.

Immunological reagents. The $\mathrm{p} 34^{\mathrm{cdc} 2}$ antibody was raised by immunizing rabbits with a peptide (CDNQIKKM) from the $\mathrm{COOH}$ terminus of $\mathrm{p} 34^{\mathrm{cdc2}}$ (GIBCO BRL). The $\mathrm{p} 33^{\mathrm{cdk2}}$ antiserum (Pharmingen, San Diego, CA) used in immunoprecipitations was produced by immunizing rabbits with a $\mathrm{COOH}$-terminal peptide (CDVTKPVPHLRL). The $\mathrm{p} 33^{\mathrm{cdk} 2}$ and $\mathrm{p} 34^{\mathrm{cdk} 4}$ antibodies used for Western blots (Santa Cruz Biotechnologies, Santa Cruz, CA) were also raised in rabbits to a $\mathrm{COOH}-$ terminal peptide of $\mathrm{p} 33^{\mathrm{cdk} 2}$ or $\mathrm{p} 34^{\mathrm{cdk} 4}$, respectively.

Cell proliferation and cell cycle analysis. Single cell suspensions were obtained from monolayers of HT-29 cells as follows. First, cells were washed with PBS, pH 7.2, supplemented with $1 \%$ BSA (PBS/ BSA), and then incubated with Hank's based Enzyme-free Cell Dissociation Solution (Specialty Media, Inc., Lavallette, NJ), as per the manufacturer's instructions. Cells were then gently scraped from the dishes in the presence of PBS/BSA supplemented with $0.05 \%$ Tween-20. Cells floating in the culture medium were harvested by low-speed centrifugation, and then pooled with the adherent cell fraction. The cells were washed and resuspended in $1 \mathrm{ml}$ of PBS/BSA. Aliquots of cells were counted using a hemacytometer and tested for viability by the trypanblue dye exclusion method. Trypan-blue (Sigma) was added to the cell suspension at a final concentration of $0.08 \%$. Cells that stained blue were considered "nonviable." Proliferation is reported as the number of cell counted at any given time point divided by the number of cells that were initially plated.

For cell cycle analysis, cells were fixed with ice-cold $70 \%$ ethanol, incubated at $-20^{\circ} \mathrm{C}$ for a minimum of $30 \mathrm{~min}$, then treated with $0.1 \%$ NP-40 for $5 \mathrm{~min}$ on ice, and then washed twice with PBS/BSA. Cells were then resuspended in $40 \mu \mathrm{g} / \mathrm{ml}$ propidium iodide (Sigma) and 200 $\mu \mathrm{g} / \mathrm{ml}$ RNase type IIA (Sigma) in PBS/BSA and incubated at room temperature for $30 \mathrm{~min}$ before measuring their DNA content using a FACS-scan (Becton Dickinson Labware, Franklin Lakes, NJ). Raw data of the distribution of DNA content retrieved from the FACS scan was expressed as a percentage of the $G_{0} / G_{1}$ through $G_{2} / M$ populations, inclusive. The MultiPlus software program (Phoenix Flow Systems, San Diego, CA) was used to generate DNA content frequency histograms and to assist in data analysis.

Thin-layer chromatography. The possibility that sulindac was converted to sulindac sulfide in the culture medium was evaluated by TLC. Culture medium was aspirated and mixed $1: 1(\mathrm{vol} / \mathrm{vol})$ with $\mathrm{CHCl}_{3} /$ $\mathrm{CH}_{3} \mathrm{OH}(1: 1, \mathrm{vol} / \mathrm{vol})$. A 10- $\mu \mathrm{l}$ aliquot from this mixture was spotted onto silica gel GF TLC plates (Analtech Inc., Newark, DE); $3 \mathrm{mM}$ solutions of authentic sulindac and sulindac sulfide were also spotted in parallel. The plates were developed with ethylacetate/acetic acid (97/ $3, \mathrm{vol} / \mathrm{vol}$ ) and the compounds were visualized by short-wave UV illumination.

Western blots. Cells were plated onto $150-\mathrm{cm}^{2}$ dishes at a density of $3 \times 10^{6}$ cells per dish and grown for $72 \mathrm{~h}$, with and without sulindac or sulindac sulfide, and were harvested as described. Their cell cycle distribution was determined by measuring the DNA content in an aliquot of these cells. The remainder of the cells were washed with PBS, lysed with 2-4 vol of $2 \times$ Laemmli's buffer without supplemental bromophenol blue $(0.12 \mathrm{M}$ Tris- $\mathrm{HCl}, \mathrm{pH} 6.8,4 \%$ SDS, $20 \%$ glycerol) (40), heated to $95^{\circ} \mathrm{C}$ for $10 \mathrm{~min}$, and then briefly sonicated. The protein content of these extracts was measured spectrophotometrically with bicinchoninic acid (41) (BCA protein assay reagent; Pierce Chem. Co., Rockford, IL). The accuracy of this method was verified by resolving a small aliquot by SDS-PAGE electrophoresis followed by Coomassie blue staining. $50 \mu \mathrm{g}$ of total protein from control and drug-treated samples were resolved on $10 \%$ SDS-PAGE gels along with prestained protein molecular weight standards (Sigma). Gels were then Western blotted onto PVDF membranes (Polyscreen (as described in Harlow and Lane [42]). Upon completion of the transfer, the membranes were blocked with 5\% milk (Carnation nonfat dry milk; Carnation Co., Los Angeles, CA) in TBS $/ 0.05 \%$ Tween-20 (TBS- 
$\mathrm{T}$ ) for a minimum of $2 \mathrm{~h}$ at room temperature. Membranes were washed with two changes of TBS-T, then reacted with the primary antibodies at a 1:1,000 dilution in 5\% milk/TBS-T for $1 \mathrm{~h}$ at room temperature. Following primary antibody incubation, the blots were washed four times with TBS-T, and then incubated with the secondary antibody, a peroxidase-conjugated goat anti-rabbit antibody (GIBCO BRL) diluted $1: 5,000$ in 5\% milk/TBS-T for a minimum of $1 \mathrm{~h}$ at room temperature. Then, after additional washing with TBS-T, the cdk proteins were detected with a chemiluminescence assay system (Renaissance NEN). After the specific proteins were visualized, the blots were stained with $0.1 \%$ India ink in TBS with $0.3 \%$ Tween-20 to verify that equal amounts of total protein were present in all of the lanes (42).

Immunoprecipitation and histone Hl kinase assays. Control and drug-treated HT-29 cells were harvested and $2 \times 10^{6}$ viable cells were lysed in the following buffer: $0.1 \% \mathrm{NP}-40,50 \mathrm{mM}$ Hepes, $\mathrm{pH} 7.5,250$ $\mathrm{mM} \mathrm{NaCl}, 100 \mu \mathrm{g} / \mathrm{ml}$ PMSF, $2 \mu \mathrm{g} / \mathrm{ml}$ aprotinin, $2 \mu \mathrm{g} / \mathrm{ml}$ leupeptin, $0.1 \mu \mathrm{g} / \mathrm{ml}$ sodium orthovanadate, $10 \mathrm{mM} \mathrm{NaF}, 5 \mathrm{mM}$ DTT, and $5 \mathrm{mM}$ EDTA. The lysates were incubated with $50 \mu \mathrm{l}$ of adult rabbit serum (Hazelton, Denver, PA) for $30 \mathrm{~min}$ and then mixed for $1 \mathrm{~h}$ with the pellet from $1 \mathrm{ml}$ of a $10 \%$ suspension of lyophilized heat killed Staphylococcus aureus, Cowan I strain (Zysorbin; Zymed Laboratories, Inc., South San Francisco, CA) followed by centrifugation at $12,500 \mathrm{~g}$ for $10 \mathrm{~min}$ as a preclearing step. For $\mathrm{p} 34^{\mathrm{cdc} 2}$ immunoprecipitations (IPs), one half of the precleared lysate was incubated with $5 \mu \mathrm{l}$ of $\mathrm{p} 34^{\mathrm{cdc} 2}$ antibody, and the other half with $5 \mu \mathrm{l}$ of normal adult rabbit serum as a negative control. Similarly for $\mathrm{p} 33^{\text {cdk2 } 2} \mathrm{IPs}$, precleared lysates were divided and one half was incubated with $5 \mu \mathrm{l}$ of a p33 $3^{\text {cdk2 }}$ antiserum and the other with $5 \mu \mathrm{l}$ of the negative control normal adult rabbit serum. After a 1 $h$ incubation on ice, the immune complexes were precipitated by incubation with protein A coupled to sepharose beads (Pharmacia Biotech, Inc., Piscataway, NJ). The beads bearing the immunoprecipitates were thoroughly washed with lysis buffer, and then with cdc2 $(50 \mathrm{mM}$ Tris$\mathrm{HCl}, \mathrm{pH} 8,10 \mathrm{mM} \mathrm{MgCl} 2,1 \mathrm{mM}$ DTT) or cdk2 (50 mM Hepes, $\mathrm{pH}$ $7,10 \mathrm{mM} \mathrm{MgCl}_{2}, 1 \mathrm{mM}$ DTT) kinase wash buffers. The beads were then pelleted and aspirated dry. Histone $\mathrm{H} 1$ kinase assays were performed by the addition of cdc2 kinase ( $50 \mathrm{mM}$ Tris- $\mathrm{HCl}, \mathrm{pH} 8,10 \mathrm{mM} \mathrm{MgCl}, 1$ mM DTT, $25 \mu \mathrm{M}$ ATP, $5 \mu \mathrm{Ci}{ }^{32} \mathrm{P} \gamma$-ATP [Dupont-NEN]) or cdk2 kinase (50 mM Hepes, $\mathrm{pH} 7,10 \mathrm{mM} \mathrm{MgCl}, 1 \mathrm{mM}$ DTT, $12.5 \mu \mathrm{M}$ ATP, $20 \mu \mathrm{Ci}{ }^{32} \mathrm{P} \gamma$-ATP) buffers supplemented with $100 \mu \mathrm{g} / \mathrm{ml}$ histone H1 (Boehringer-Mannheim Corp., Indianapolis, IN). The kinase assays, performed at room temperature for $30 \mathrm{~min}$, were terminated by the addition of $2 \times$ Laemmli's buffer containing $200 \mathrm{mM}$ DTT. The products of these reactions were resolved on 10\% SDS-PAGE gels. Upon completion of the electrophoresis, gels were immersed in $0.25 \%$ Coomassie blue, followed by destaining with $0.25 \% \mathrm{MeOH}$ and $0.07 \%$ acetic acid, then by autoradiography. Following visualization of the ${ }^{32} \mathrm{P}$-labeled histone $\mathrm{H} 1$ in this manner, the Coomassie-stained histone $\mathrm{H} 1$ bands were excised from the gels. The degree of incorporation of ${ }^{32} \mathrm{P}$ into the histone $\mathrm{H} 1$ present in the individual gel slices, expressed as cpm emitted from the samples, was determined in a scintillation counter (Beckman Instruments, Inc., Fullerton, CA) by the Cerenkov method.

Apoptosis. The cells were evaluated for evidence of apoptosis by three different assays: $(a)$ measurement of the DNA content of cells by propidium iodide staining and FACS analysis $(43,44)$, to detect a subdiploid peak of DNA, indicative of the DNA fragmentation occurring with apoptosis; $(b)$ acridine orange staining to identify cellular morphologic changes characteristic of apoptosis (45); and (c) agarose gel electrophoresis of genomic DNA to detect the DNA degradation associated with apoptosis (46).

Acridine orange staining. Single cell suspensions of control and drug-treated HT-29 cells in PBS/BSA were fixed with 70\% ethanol and frozen at $-20^{\circ} \mathrm{C}$ for at least $30 \mathrm{~min}$. They were washed and resuspended in PBS and treated with ice-cold $0.1 \%$ Triton X-100, $0.08 \mathrm{~N} \mathrm{HCl}$, and $0.15 \mathrm{M} \mathrm{NaCl}$. The cells were then stained with $20 \mu \mathrm{M}$ acridine orange (Sigma) in a phosphate-citric acid buffer (pH 6) containing $1 \mathrm{mM}$ EDTA and $0.15 \mathrm{M} \mathrm{NaCl}$. The suspension of stained cells was centrifuged at $750 \mathrm{~g}$ and cells were then resuspended in PBS. One drop of this suspension was placed on a microscope slide and the cells were evalu- ated by UV fluorescence microscopy. The morphologic criteria used to quantify the fraction of apoptotic cells on these slides included the presence of: $(a)$ cytoplasmic and nuclear shrinkage; $(b)$ chromatin condensation; and (c) cytoplasmic blebbing with maintenance of the integrity of the cell membrane (zeiosis) (37). The percentage of apoptotic cells among all of the cells present on the slide was determined by counting 10 randomly selected high-power fields.

For fluorescence microscopy, 50,000 freshly harvested cells from control or drug-treated dishes were applied to glass slides by centrifugation at 1,000 rpm in a cytospin well (Cytospin 2; Shandon Inc., Pittsburgh, PA) for $5 \mathrm{~min}$. The slides were fixed by immersion in acetic acid/ethanol $(1: 9, \mathrm{vol} / \mathrm{vol})$ for at least $20 \mathrm{~min}$. Upon drying, the slides were treated with HBSS, and stained with acridine orange as above. Following several washes with HBSS, the cells were examined with a UV fluorescence microscope and photographed (Labophot, Nikon Inc.).

DNA degradation. HT-29 cells were plated at a density of $3 \times 10^{6}$ cells/dish and treated with control or drug-supplemented medium for $72 \mathrm{~h}$. HL-60 cells, plated at a density of $0.4 \times 10^{6} \mathrm{cells} / \mathrm{ml}$, were treated with control or drug-supplemented medium for $4 \mathrm{~h}$. Genomic DNA was obtained from $1 \times 10^{6}$ HT-29 cells (both viable and nonviable) and $2-5 \times 10^{6} \mathrm{HL}-60$ cells by lysis in $0.04 \mathrm{M}$ Tris-Acetate, $1 \mathrm{mM}$ EDTA, $0.25 \% \mathrm{NP}-40$. These extracts were digested with $100 \mu \mathrm{g} / \mathrm{ml}$ boiled RNase IIA (Sigma) for $1 \mathrm{~h}$ at $37^{\circ} \mathrm{C}$ followed by treatment with proteinase $\mathrm{K}$ (Boehringer-Mannheim) at a concentration of $1 \mathrm{mg} / \mathrm{ml}$ at $37^{\circ} \mathrm{C}$ for $18 \mathrm{~h}$. Aliquots of DNA from the equivalent of $1-2 \times 10^{5}$ cells, were mixed with sample buffer (final concentration: $0.025 \%$ bromophenol blue $/ \pm 0.025 \%$ xylene cyanole $/ 3.0 \%$ glycerol ) and resolved in $1.8 \%$ agarose gels impregnated with ethidium bromide $(0.1 \mu \mathrm{g} / \mathrm{ml})$. To analyze greater amounts of DNA, isolated genomic DNA was extracted with phenol:chloroform $(1: 1, \mathrm{vol} / \mathrm{vol})$ then chloroform, followed by ethanol precipitation. The resulting DNA was dissolved in $\mathrm{H}_{2} \mathrm{O}$ and its amount present in solution was quantified by measuring its absorbance at $260 \mathrm{~nm} .10 \mu \mathrm{g}$ of this DNA, mixed with sample buffer, was resolved on $1.8 \%$ agarose gels. DNA was visualized by UV transillumination and photographed using Polaroid 667 Film.

\section{Results}

Sulindac and its metabolite, sulindac sulfide, reduce the proliferation and alter the morphology of HT-29 adenocarcinoma cells

Sulindac and sulindac sulfide reduce the proliferation of HT-29 cells. To evaluate the effect of sulindac and sulindac sulfide on the proliferation rates of colon cancer cells in vitro, HT-29 cells were plated at a density of $0.75-1.0 \times 10^{6}$ cells per $100-\mathrm{cm}^{2}$ tissue culture dish or at a density of $3.0 \times 10^{6}$ cells per $150-\mathrm{cm}^{2} \mathrm{dish}$, with or without sulindac or sulindac sulfide supplemented in the culture medium. Cells were harvested 24,48 , or $72 \mathrm{~h}$ after plating. The number of viable cells present in the culture dishes, following incubation with either sulindac-supplemented $(100,200,400,600$, and $1,200 \mu \mathrm{M})$ or control medium, is shown in Fig. 1. This figure demonstrates that control HT-29 colon cancer cells entered log growth phase $\sim 24 \mathrm{~h}$ after plating. Cells treated with sulindac exhibit a profound concentration-dependent reduction in their proliferation rate over the 72 -h test period. At sulindac $1,200 \mu \mathrm{M}$, the proliferation curve was flat, i.e., there was no net increase in the number of viable cells following treatment with this concentration over the entire $72 \mathrm{~h}$.

Sulindac sulfide, the reduced molecular species of sulindac, also inhibited the accumulation of HT-29 cells. It was more potent than sulindac in inhibiting HT-29 cell proliferation. As illustrated in Fig. 2, compared to the control cells (grown in McCoy's medium supplemented with $0.6 \%$ DMSO), sulindac sulfide caused a concentration-dependent reduction in HT-29 


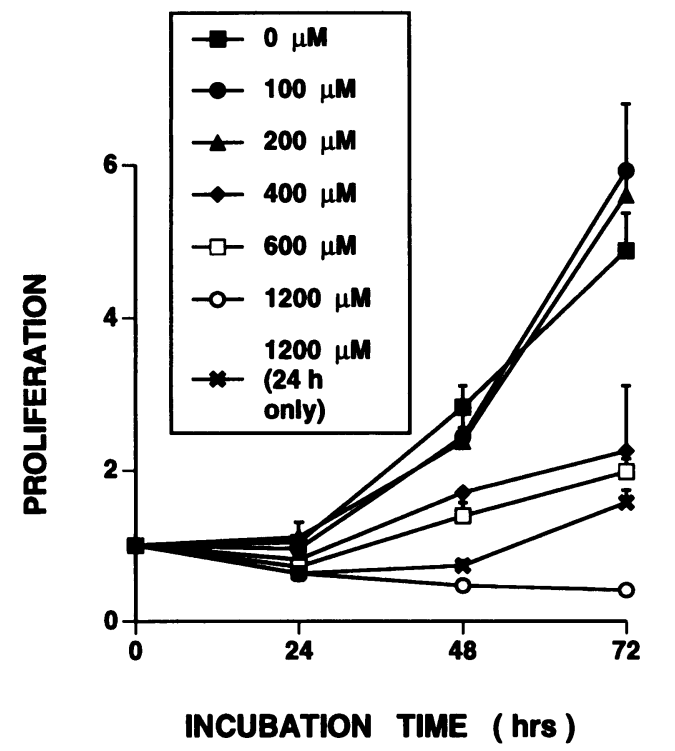

Figure 1. Growth of HT-29 cells treated with sulindac. Cells were grown in the presence of various concentrations of sulindac for $72 \mathrm{~h}$ and counted, as described in Methods. - $\mathbf{x}$ - line represents the reversibility study: cells were treated with sulindac $1,200 \mu \mathrm{M}$ for only $24 \mathrm{~h}$, when the sulindac-supplemented medium was replaced by control medium for an additional 24 or $48 \mathrm{~h}$. The values for proliferation are the ratio between the number of cells counted at each time point divided by the number initially plated. Values are mean \pm SEM ( $n$ ranges between 6 and 20).

cell proliferation. At 175 and $200 \mu \mathrm{M}$, sulindac sulfide strongly inhibited the proliferation of these cells, with a sustained diminution of the number of viable cells throughout the 72 -h treatment period.

It should be emphasized that sulindac sulfide was added to the culture dishes at concentrations that we estimated are achievable in vivo in colon tissue (see below).

Sulindac and sulindac sulfide alter the morphology of HT29 cells. Sulindac and sulindac sulfide treatment induced distinctive morphological changes in HT-29 cells. Normally, $72 \mathrm{~h}$ after being plated at a density of $1 \times 10^{6}$ cells per $100-\mathrm{cm}^{2}$ dish with control medium supplemented with $0.6 \%$ DMSO, HT-29 cells grow in aggregates with individual cells assuming polygonal or rectangular shapes (a representative area is shown in Fig. $3 a$ ). Cells treated with $150 \mu \mathrm{M}$ sulindac sulfide (Fig. $3 \mathrm{~b}$ ) for $72 \mathrm{~h}$ also grew in groups, but developed elongated cellular processes and assumed unusual shapes. Treatment with $200 \mu \mathrm{M}$ sulindac sulfide for $72 \mathrm{~h}$ induced striking morphological changes in these cells. As demonstrated in Fig. $3 c$, these cells grew as small, single cells, often separated from neighboring cells, and displayed prominent long filamentous processes. These processes were similar to, but more prominent than, those seen following treatment with lower concentrations of sulindac sulfide (Fig. $3 \mathrm{~b}$ ). In addition, cells treated with $200 \mu \mathrm{M}$ sulindac sulfide developed small, round, and highly refractile intracellular bodies distributed throughout their cytoplasm (Fig. 3 c). These changes were evident as early as 12 to $24 \mathrm{~h}$ after incubation of the HT-29 cells with sulindac sulfide (data not shown).

Sulindac treatment resulted in similar, if not identical, morphological changes in these cells, but at higher concentrations

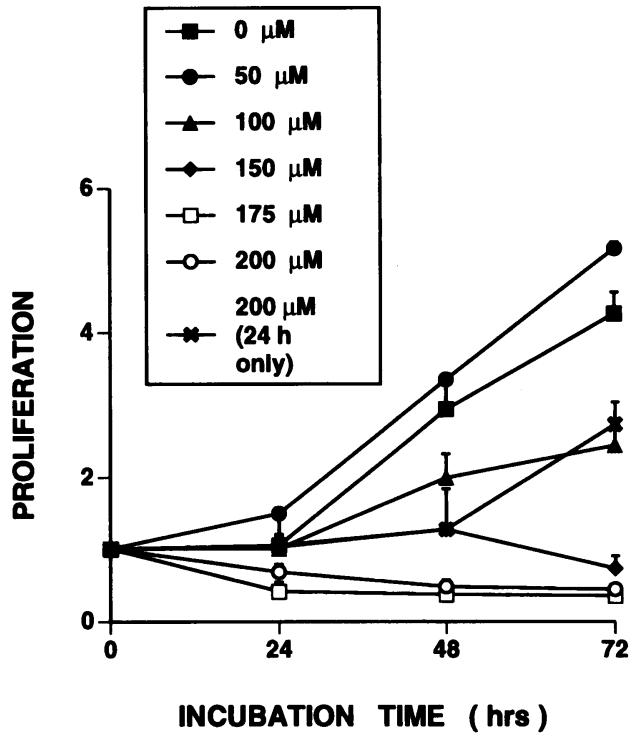

Figure 2. Growth of HT-29 cells treated with sulindac sulfide. Cells were grown in the presence of various concentrations of sulindac sulfide for $72 \mathrm{~h}$ and counted, as described in Methods. $-\mathbf{x}$ - line represents the reversibility study: cells were treated with sulindac sulfide $200 \mu \mathrm{M}$ for only $24 \mathrm{~h}$, when the sulindac sulfide-supplemented medium was replaced by control medium for an additional 24 or $48 \mathrm{~h}$. The values for proliferation are the ratio between the number of cells counted at each time point divided by the number initially plated. Values are mean \pm SEM ( $n$ ranges between 5 and 30 ).

than were required to see an effect with sulindac sulfide. Sulindac $1,200 \mu \mathrm{M}$ (Fig. $3 \mathrm{~g}$ ) induced the alterations in cell morphology similar to those seen with $200 \mu \mathrm{M}$ sulindac sulfide (Fig. 3 $c$ ). In addition, sulindac $600 \mu \mathrm{M}$ (Fig. $3 f$ ) induced changes similar to those seen at the $150 \mu \mathrm{M}$ concentration of sulindac sulfide (Fig. $3 b$ ). These morphological changes were also evident as early as 12 to $24 \mathrm{~h}$ after incubation with sulindac (data not shown). In addition, there was virtually no difference in the morphology of cells incubated in medium with (Fig. $3 a$ ) or without (Fig. $3 e$ ) supplemental DMSO at a concentration of $0.6 \%$.

The effect of sulindac and sulindac sulfide on the proliferation and morphology of HT-29 cells is reversible. We assessed whether the effects of sulindac and sulindac sulfide on HT-29 cell proliferation and morphology were reversible. Cells were treated with sulindac $(1,200 \mu \mathrm{M})$ or sulindac sulfide $(200 \mu \mathrm{M})$ for $24 \mathrm{~h}$, then were washed and refed with control medium (McCoy's or McCoy's supplemented with $0.6 \%$ DMSO) and allowed to grow for an additional 24 or $48 \mathrm{~h}$. As shown in Fig. 1, the proliferation rate of cells initially treated with high concentrations $(1,200 \mu \mathrm{M})$ of sulindac approached that of the control cells $48 \mathrm{~h}$ after replacement of drug-supplemented medium with control medium. At this time, these cells assumed the morphological characteristics of control cells (Fig. $3 h$ ).

Sulindac sulfide also had a reversible effect on HT-29 cell proliferation and morphology. As shown in Fig. 2, cells treated with sulindac sulfide $(200 \mu \mathrm{M})$ for the initial $24 \mathrm{~h}$ achieved proliferation rates approaching those of the control cells $48 \mathrm{~h}$ after replacement of drug-supplemented medium with control medium. Likewise, these cells then assumed normal shapes and sizes (Fig. $3 d$ ). The morphologic alterations were rapidly re- 


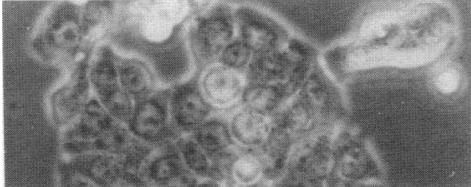

(a)

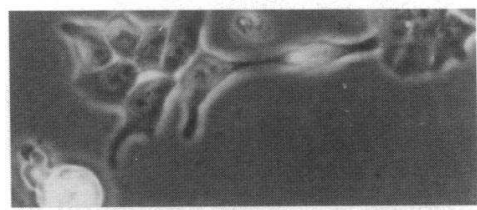

(b)

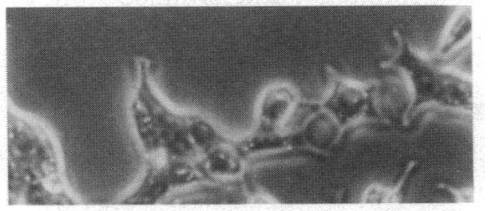

(c)

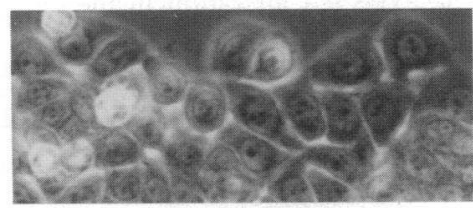

(d)

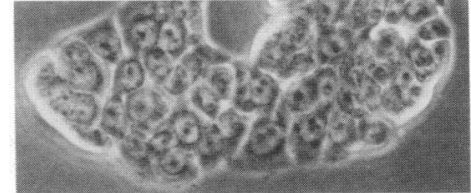

(e)

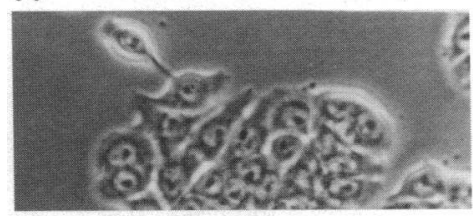

(f)

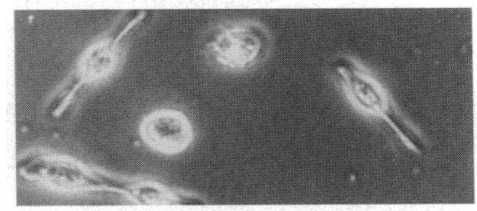

(g)

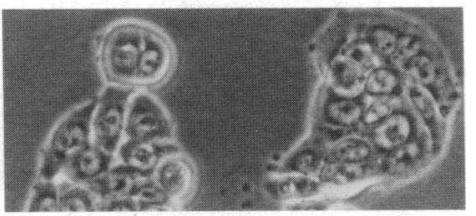

(h)

Figure 3. Photomicrographs of HT-29 cells treated with sulindac sulfide or sulindac. Cells were treated with various concentrations of sulindac sulfide $(a, 0 \mu \mathrm{M} ; b$, $150 \mu \mathrm{M} ; c, 200 \mu \mathrm{M})$ for $72 \mathrm{~h}$; or with $200 \mu \mathrm{M}$ for only $24 \mathrm{~h}(d)$, when the sulindac sulfide-supplemented medium was replaced with control medium for an additional $48 \mathrm{~h}$. Similarly, cells were treated with sulindac $(e, 0 \mu \mathrm{M} ; f, 600 \mu \mathrm{M} ; g, 1,200 \mu \mathrm{M})$ for $72 \mathrm{~h}$, or with $1,200 \mu \mathrm{M}$ for only $24 \mathrm{~h}(h)$, when the sulindac-supplemented medium was replaced by control medium for an additional $48 \mathrm{~h}$. Only areas portraying the representative morphologic changes of the cells throughout the entire dish were photographed and presented in this figure. $\times 40$.

versed (data not shown), often $24 \mathrm{~h}$ after removal of sulindac sulfide.

\section{The effect of sulindac is not mediated exclusively by} conversion to sulindac sulfide in the culture medium

Since sulindac sulfide reduced HT-29 cell proliferation and altered their morphology at concentrations approximately sixtimes lower than its parent compound, we evaluated whether sulindac was converted to sulindac sulfide in the culture medium bathing the cells to a degree that would suggest sulindac sulfide was the mediator of the effect of sulindac on these cells. To address this, HT-29 cells were incubated with either control medium or with sulindac- or sulindac sulfide-supplemented medium. $72 \mathrm{~h}$ after plating, the medium was aspirated from the dishes and an aliquot was resolved by thin layer chromatography. A chromatogram of control and drug-supplemented culture

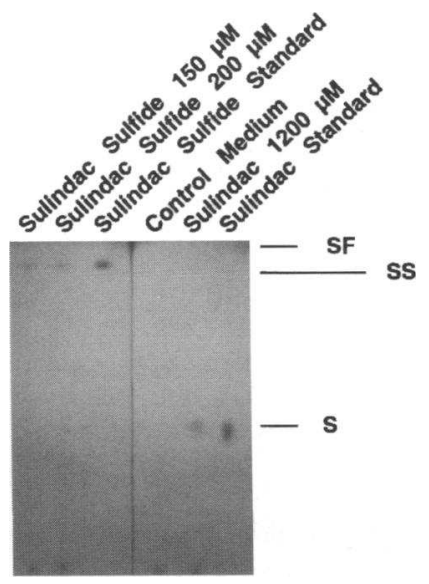

Figure 4. Thin layer chromatogram of sulindac and sulindac sulfide. Medium from HT-29 cells treated with sulindac 1,200 $\mu \mathrm{M}$ or sulindac sulfide 150 and $200 \mu \mathrm{M}$ was applied to TLC plates, along with authentic compounds $(3 \mathrm{mM})(S$, sulindac, $S S$, sulindac sulfide) and resolved, as described in Methods. $S F$, solvent front. media is shown in Fig. 4. At concentrations previously demonstrated to inhibit HT-29 cell proliferation, we did not detect appreciable conversion of sulindac to sulindac sulfide, or vice versa, in the medium bathing the cells after $72 \mathrm{~h}$ of incubation. This figure shows that sulindac $1,200 \mu \mathrm{M}$ was not converted to sulindac sulfide, at least to levels approaching $150 \mu \mathrm{M}$, which produced a comparable effect on proliferation and morphology.

Sulindac and sulindac sulfide alter the distribution of DNA content of HT-29 cells

To explore the mechanism responsible for the anti-proliferative effect of sulindac and sulindac sulfide treatment on HT-29 colon adenocarcinoma cells, we assessed the effect of these compounds on their cell division cycle. Cells treated with the test compounds were harvested 24,48 , or $72 \mathrm{~h}$ after plating, and their DNA content was assessed. The cell cycle phase distribution of HT-29 cells incubated for $72 \mathrm{~h}$ in control or sulindacsupplemented medium (between 100 and $1,200 \mu \mathrm{M}$ ) is shown in Table I (top). At $48 \mathrm{~h}$, the change in the cell cycle phase distribution in response to sulindac was concentration-dependent between 400 and 1,200 $\mu \mathrm{M}$. At $72 \mathrm{~h}$, sulindac caused a nonlinear concentration-dependent alteration in the cell cycle phase distribution of these cells; with a significant effect noted only at its highest concentration. At the $1,200 \mu \mathrm{M}$ concentration, sulindac increased the proportion of cells in the $G_{0} / G_{1}$ phase and decreased the proportion in the $S$ and $G_{2} / M$ phases of the cell cycle. Fig. 5 also shows the cell cycle phase distribution of control and sulindac-treated cells harvested at 24,48 , and 72 $\mathrm{h}$ after plating. As is evident in this figure, the effect of sulindac $1,200 \mu \mathrm{M}$ on the redistribution of cells in the cell cycle was recognized as early as $24 \mathrm{~h}$ after the cells were plated and persisted throughout the entire 72-h treatment period.

Like sulindac, sulindac sulfide treatment produced a concen- 
Table I. Cell Cycle Phase Distribution of HT-29 Cells Treated with Sulindac or Sulindac Sulfide for $72 h$

\begin{tabular}{lrrr}
\hline Concentration $(\mu \mathrm{M})$ & $\% \mathrm{G}_{0} / \mathrm{G}_{1}$ & $\% \mathrm{~S}$ & $\% \mathrm{G}_{2} / \mathrm{M}$ \\
\hline Sulindac & & & \\
0 & $52.4 \pm 2.0$ & $21.6 \pm 1.3$ & $24.9 \pm 2.1$ \\
100 & $56.4 \pm 3.2$ & $25.5 \pm 5.7$ & $17.8 \pm 3.3$ \\
200 & $54.5 \pm 4.1$ & $24.8 \pm 5.6$ & $20.1 \pm 8.8$ \\
400 & $50.4 \pm 1.8$ & $14.6 \pm 0.6$ & $33.4 \pm 2.1$ \\
200 & $51.6 \pm 2.0$ & $18.3 \pm 1.1$ & $29.3 \pm 1.8$ \\
1200 & $77.5 \pm 3.5$ & $8.4 \pm 2.3$ & $14.1 \pm 2.4$ \\
1200 (24 h only) & $50.2 \pm 0.4$ & $30.0 \pm 2.4$ & $20.4 \pm 2.0$ \\
Sulindac sulfide & & & \\
0 & $51.4 \pm 1.7$ & $20.1 \pm 1.2$ & $26.6 \pm 1.9$ \\
50 & $54.8 \pm 0.9$ & $19.1 \pm 0.6$ & $26.3 \pm 0.3$ \\
100 & $52.2 \pm 1.9$ & $23.1 \pm 1.4$ & $23.1 \pm 1.4$ \\
150 & $69.3 \pm 2.7$ & $11.5 \pm 1.2$ & $17.2 \pm 1.8$ \\
175 & $80.5 \pm 2.6$ & $8.4 \pm 0.7$ & $11.2 \pm 2.1$ \\
200 & $79.3 \pm 1.8$ & $7.3 \pm 0.9$ & $11.7 \pm 1.7$ \\
200 (24 h only) & $15.6 \pm 6.3$ & $26.0 \pm 1.1$ & $57.8 \pm 5.2$ \\
& & & \\
\hline
\end{tabular}

In each panel, the last row of results represents a reversibility study; cells were treated with sulindac $1,200 \mu \mathrm{M}$ or sulindac sulfide $200 \mu \mathrm{M}$ for $24 \mathrm{~h}$, when the medium was replaced with control medium for an additional $48 \mathrm{~h}$ before harvest and FACS analysis. Values are mean $\pm \operatorname{SEM}(n$ ranges between 6 and 25 ).

tration-dependent effect on the cell cycle phase distribution of HT-29 cells, but again at a lower concentration range. Also like sulindac, the concentration dependence was not linear. Compared to controls, at $72 \mathrm{~h}$ sulindac sulfide markedly increased the proportion of cells in $G_{0} / G_{1}$ and markedly decreased the proportion of cells in the $S$ and $\mathrm{G}_{2} / \mathrm{M}$ phases (Table $\mathrm{I}$, bottom). This effect was evident as early as $24 \mathrm{~h}$ after plating at $\geq 150$ $\mu \mathrm{M}$ and persisted for the entire 72-h experimental period (Fig. 6). Fig. 7 shows DNA content frequency histograms from control and sulindac sulfide-treated cells after $72 \mathrm{~h}$ of incubation. The changes in the cell cycle phase distribution in response to sulindac sulfide are also clearly visible in this figure which also demonstrates the appearance of a sub-diploid peak in the sulindac sulfide-treated cells (Fig. 7 middle and see below). Sulindac-treated cells did not manifest such a sub-diploid peak after $72 \mathrm{~h}$ of incubation (data not shown).

The effect of both sulindac and sulindac sulfide on the cell cycle phase distribution of HT-29 cells was reversible. Figs. 5 and 6 and Table I show the cell cycle phase distribution of HT29 cells 24 or $48 \mathrm{~h}$ after a 24 -h period of treatment with sulindac $(1,200 \mu \mathrm{M})$ or sulindac sulfide $(200 \mu \mathrm{M})$. Fig. $5 b$ shows that $24 \mathrm{~h}$ after the removal of $1,200 \mu \mathrm{M}$ sulindac, a lower proportion of the cells were in $G_{0} / G_{1}$ and a greater percentage in $S$ phase compared to control and sulindac-treated cells. $48 \mathrm{~h}$ after removal of sulindac, the cell cycle phase distribution was no different from control cells (Fig. $5 c$ and Table I, top).

After the removal of $200 \mu \mathrm{M}$ sulindac sulfide from the culture medium 24 or $48 \mathrm{~h}$ after an initial period of drug treatment, a lower proportion of the cells were in $G_{0} / G_{1}$ and a higher percentage in the $S$ and $G_{2} / M$ phases compared to either control cells or those continuously treated with sulindac sulfide (Figs. $6, b$ and $c$ and 7, bottom, and Table I, bottom).
Sulindac and sulindac sulfide reduce the level of $p 34^{\text {cdc2 }}$, p33 ${ }^{\text {cdk }}$, and p34 $4^{\text {cdk4 }}$ in HT-29 colon cancer cells

Since high concentrations of sulindac and sulindac sulfide had such a marked effect on the cell cycle distribution of HT-29 colon cancer cells, we evaluated potential molecular mechanism(s) related to this effect. Inhibition of the activity of selected cyclin-dependent kinases, has been shown in many systems to induce cell cycle arrest (18). We wished to determine whether drug treatment could alter the levels and activity of certain cdks that are critical for the regulation of cell cycle progression in eukaryotic cells. Therefore, the relative levels of the cdks, p34 cdc2 and p33 cdk2 , and p34 cdk4 were determined in extracts prepared from control, sulindac-, and sulindac sulfidetreated cells by Western blot. As illustrated in Fig. $8 a$, sulindac and sulindac sulfide led to a reduction in the level of $\mathrm{p} 34^{\text {cdc2 }}$ protein. This effect was maximal at $1,200 \mu \mathrm{M}$ sulindac and 175 $\mu \mathrm{M}$ sulindac sulfide, where little $\mathrm{p} 34^{\mathrm{cdc} 2}$ protein was detectable. The cell cycle phase distribution was measured in parallel from an aliquot of the cells collected in this experiment. As is demonstrated in Fig. 8 (bottom), the expected alteration in the cell cycle phase distribution (high $G_{0} / G_{1}$ and low $S$ and $G_{2} / M$ phases) was also observed with sulindac $1,200 \mu \mathrm{M}$ and sulindac sulfide $175 \mu \mathrm{M}$. As is shown in Fig. $8 b$, sulindac $1,200 \mu \mathrm{M}$ and sulindac sulfide $175 \mu \mathrm{M}$ profoundly reduced the level of
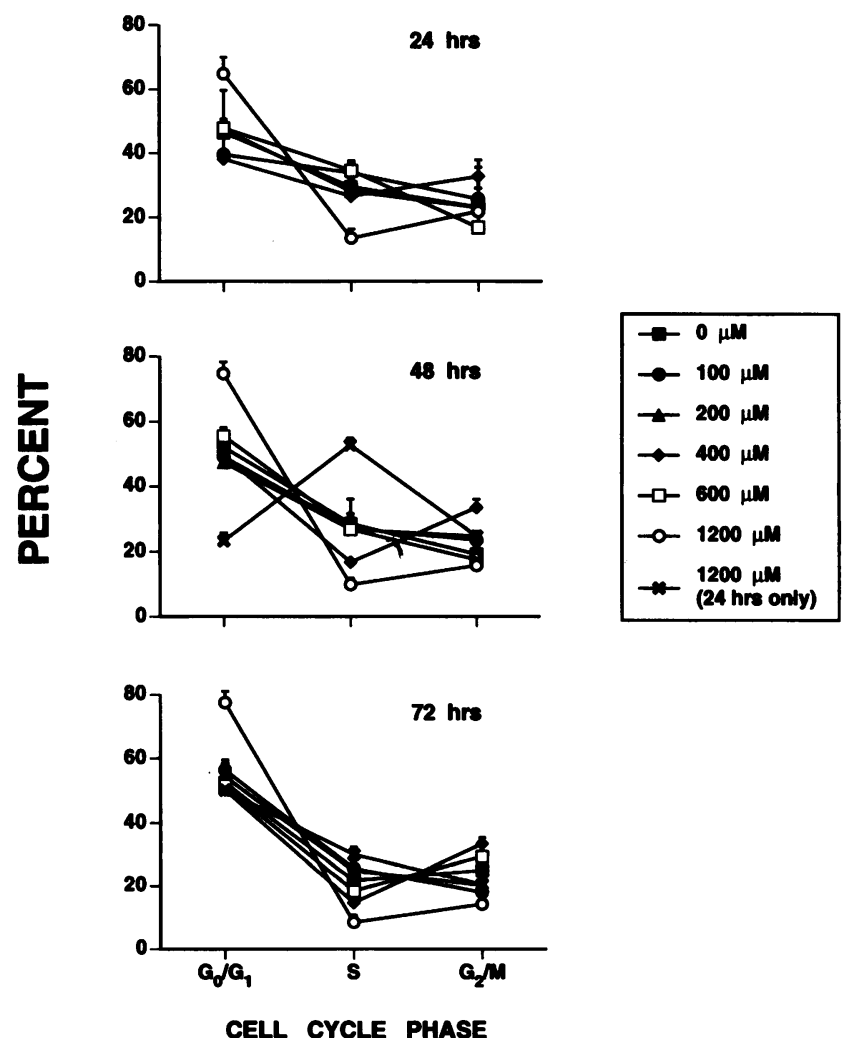

Figure 5. Cell cycle phase distribution of HT-29 cells treated with sulindac. HT-29 cells were treated with various concentrations of sulindac and harvested at $24(a), 48(b)$, or $72(c)$ h. Their cell cycle phase distribution was determined by FACS analysis, as described in Methods. $-\mathbf{X}-$ in $b$ and $c$ represents the reversibility study: cells were treated with sulindac $1,200 \mu \mathrm{M}$ for only $24 \mathrm{~h}$, when the sulindac-supplemented medium was replaced by control medium for an additional 24 (b) or 48 (c) h. Values are mean \pm SEM ( $n$ ranges between 6 and 20). 

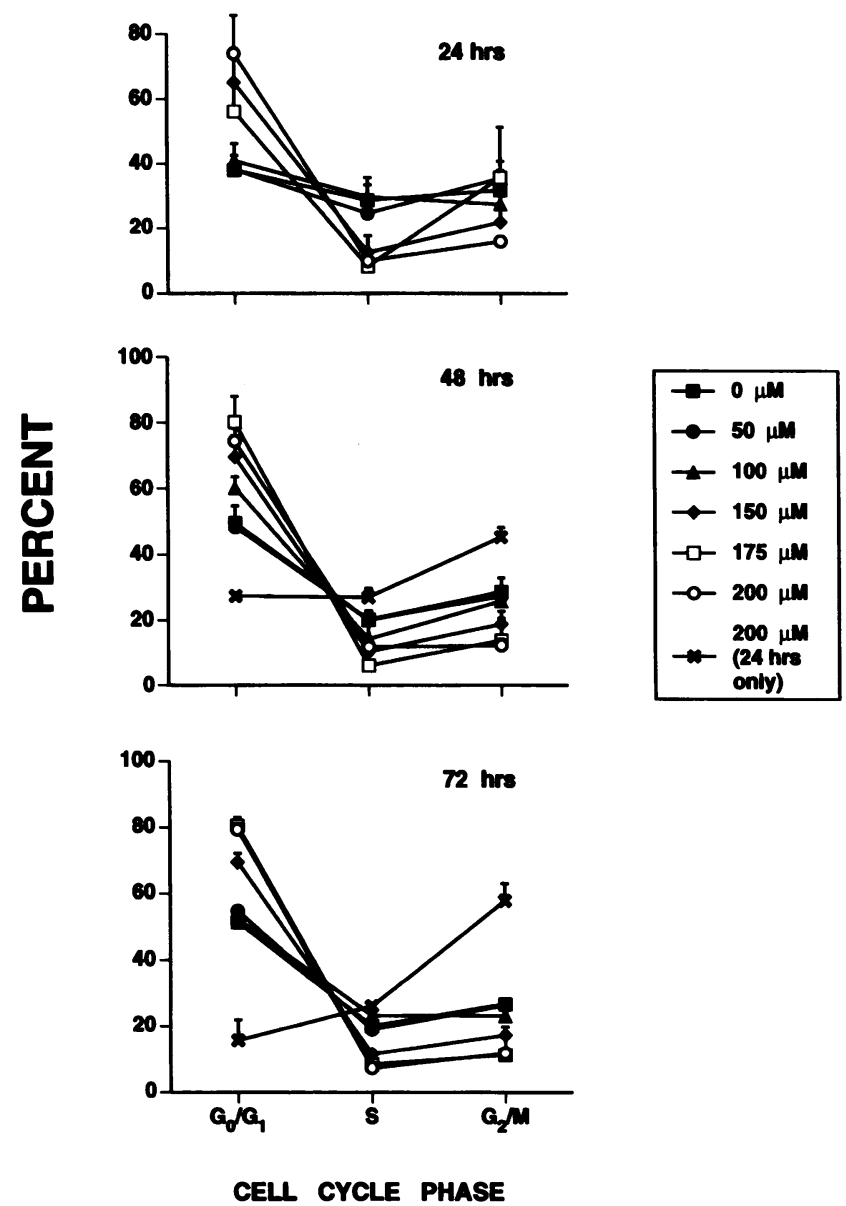

Figure 6. Cell cycle phase distribution of HT-29 cells treated with sulindac sulfide. HT-29 cells were treated with various concentrations of sulindac sulfide and harvested at $24(a), 48(b)$, or $72(c) \mathrm{h}$. Their cell cycle phase distribution was determined by FACS analysis, as described in Methods. - $\mathbf{x}-$ in $b$ and $c$ represents the reversibility study: cells were treated with sulindac sulfide $200 \mu \mathrm{M}$ for only $24 \mathrm{~h}$, when the sulindac sulfide-supplemented medium was replaced by control medium for an additional $24(b)$ or $48(c)$ h. Values are mean \pm SEM $(n$ ranges between 5 and 30 ).

$\mathrm{p} 33^{\mathrm{cdk} 2}$ protein, which regulates the $\mathrm{G}_{1}$ to $\mathrm{S}$ transition. Finally, Fig. $8 c$ shows that high concentrations of sulindac and sulindac sulfide also reduced the level of p34 ${ }^{\text {cdk4 }}$, though to a lesser extent than the other cdks. Lower concentrations of sulindac $(600 \mu \mathrm{M})$ and sulindac sulfide $(100 \mu \mathrm{M})$ resulted in minimal, if any, reduction in levels of $\mathrm{p} 34^{\text {cdc2 }}, \mathrm{p} 33^{\text {cdk2 }}$, or p34 ${ }^{\text {cdk4 }}$ (Fig. $8, a-c)$. In addition, as expected, the lower concentrations of these compounds did not affect the cell cycle phase distribution of these cells (Fig. 8, bottom, Figs. 5 and 6). Therefore, the changes in the abundance of the cdk proteins were noted only when sulindac and sulindac sulfide induced an effect on the cell cycle in these cells.

To confirm that equal amounts of total protein were loaded in each of the lanes on these blots, after they were probed with the appropriate antibodies, they were treated with India ink to visualize the total protein content in all of the lanes. There were approximately equal amounts of total protein in all of the lanes of these membranes, including the lanes where the cdks were profoundly reduced (data not shown).

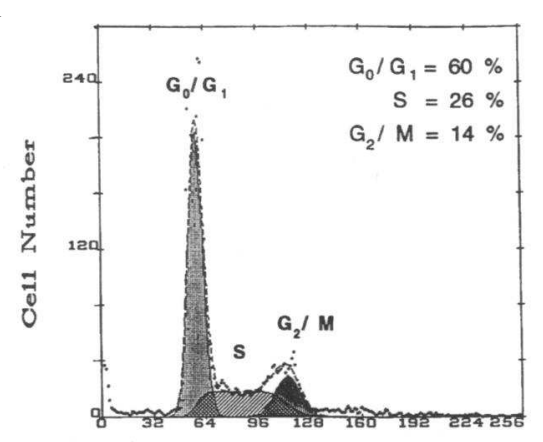

Control + DMSO

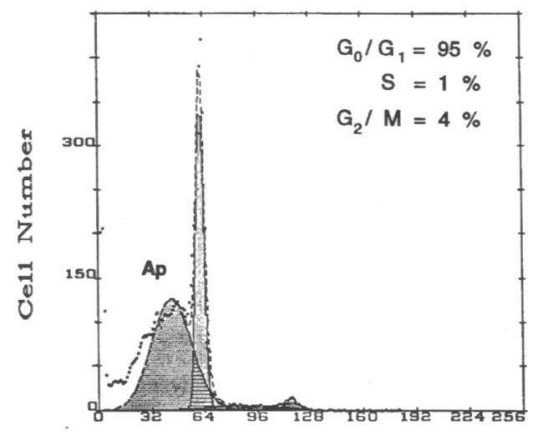

Sulindac Sulfide $200 \mu \mathrm{M}$

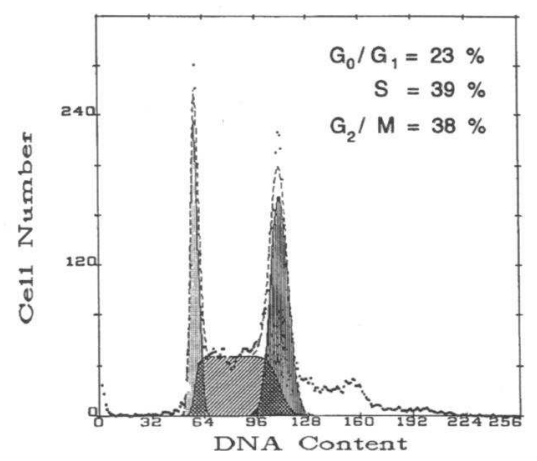

Sulindac Sulfide $200 \mu \mathrm{M}$ (24 hrs only)

Figure 7. DNA content frequency histograms of HT-29 cells treated with sulindac sulfide. Cells were treated with $200 \mu \mathrm{M}$ sulindac sulfide for $72 \mathrm{~h}$ and their DNA content was determined by FACS, as described in Methods. (Top) Control cells. (Middle) sulindac sulfide-treated cells. (Bottom) Reversibility study: cells were treated with sulindac sulfide for $24 \mathrm{~h}$, when the sulindac sulfide-supplemented medium was replaced by control medium for an additional $48 \mathrm{~h}$. The cell cycle phase distributions for each treatment are indicated within each panel. Sulindac sulfide-treated cells developed a novel peak below the $G_{0} / G_{1}$ position on the histograms $(A p)$, which corresponds to apoptotic HT-29 cells.

Longer exposures of these Western blots revealed very low levels of cdk proteins in the lanes containing proteins extracted from cells treated with sulindac $1,200 \mu \mathrm{M}$ and sulindac sulfide $175 \mu \mathrm{M}$ (data not shown). Upon determining that the level of these cdks were severely reduced by sulindac and sulindac sulfide treatment, we then examined whether the reduction in cdk levels was accompanied by a change in their enzymatic activity. Therefore, immunoprecipitation-histone H1 kinase assays, using lysates from control and sulindac- and sulindac sulfide- 


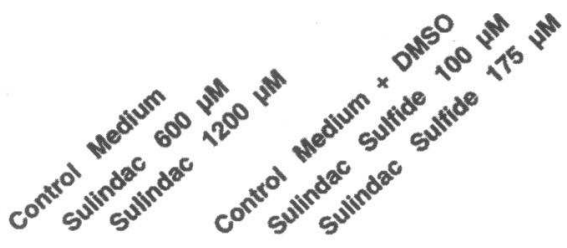

(a) $88 \mathrm{~K}-$

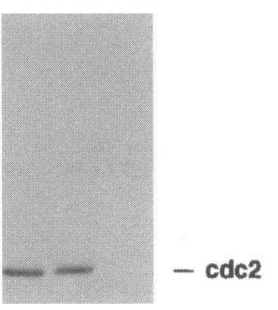

(b) $88 \mathrm{~K}$
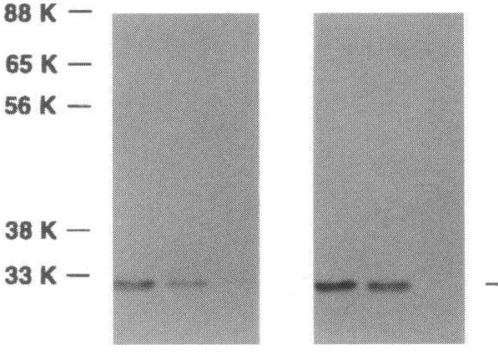

- cdk2

(c) $88 \mathrm{~K}$
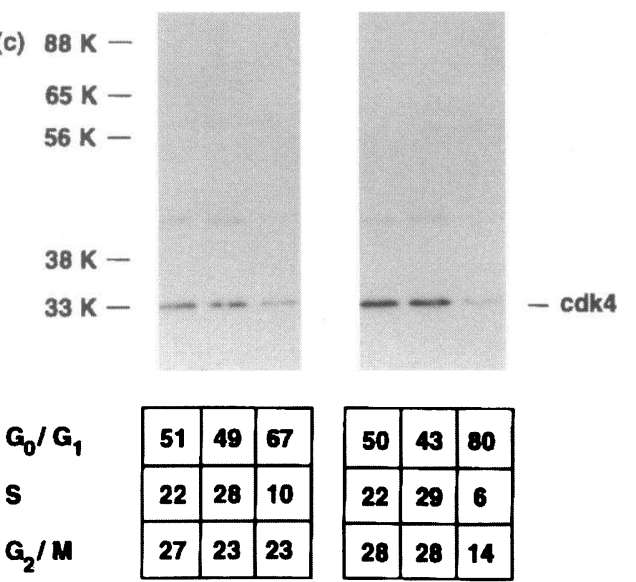

Figure 8. Western blots of cdk proteins from HT-29 cells treated with sulindac or sulindac sulfide. Cells were treated with either sulindac (600 or $1,200 \mu \mathrm{M})$ or sulindac sulfide $(100$ or $175 \mu \mathrm{M})$. Proteins $\left(a, \mathrm{p} 34^{\text {cdc2 }}\right.$; $\left.b, \mathrm{p} 33^{\mathrm{cdk} 2} ; c, \mathrm{p} 34^{\mathrm{cdk} 4}\right)$ were extracted, fractionated on $10 \%$ SDS-PAGE gels, and Western blots performed, as described in Methods. The cell cycle phase distribution of these cells (bottom) was determined in an aliquot of these cells by FACS analysis, as described in Methods. The positions of molecular weight standards are depicted to the left of each panel. The levels of all three cdks were decreased in response to sulindac $1,200 \mu \mathrm{M}$ and sulindac sulfide $175 \mu \mathrm{M}$; there was little or no change in response to lower concentrations of these compounds. The faint band in the lower panels $(c)$ has not been identified. This protocol was repeated two additional times and similar results were obtained each time.

treated cells, were performed to measure the in vitro catalytic activity of $\mathrm{p} 34^{\mathrm{cdc} 2}$ and $\mathrm{p} 33^{\mathrm{cdk} 2}(47)$ in these cells. We did not measure the in vitro activity of $\mathrm{p} 34^{\text {cdk4 }}$ in this study. As shown in Fig. 9, $a$ and $b$, there was a severe reduction in the histone $\mathrm{H} 1$ kinase activity of $\mathrm{p} 34^{\mathrm{cdc} 2}$ and $\mathrm{p} 33^{\mathrm{cdk} 2}$, measured by the intensity of the substrate histone $\mathrm{H} 1$ bands on the gels and by their (a)

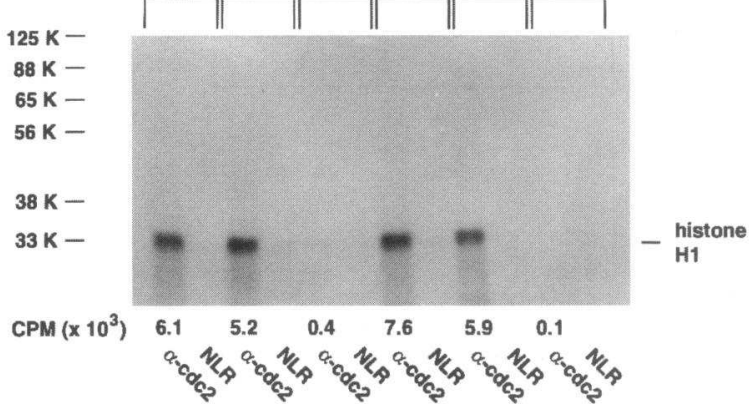

(b)

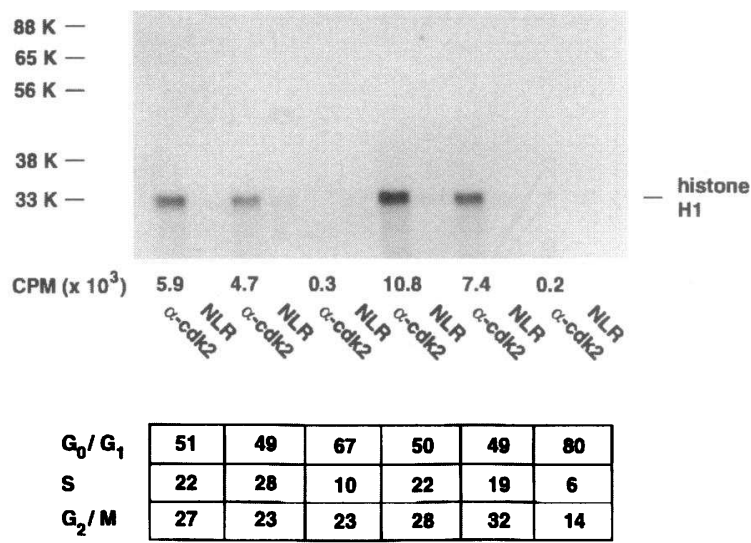

Figure 9. Histone H1 kinase assays of HT-29 cells treated with sulindac or sulindac sulfide. p34 $4^{\mathrm{cdc} 2}$ and $\mathrm{p} 34^{\mathrm{cdk} 2}$ were immunopurified in native form from a lysate of HT-29 cells treated with either sulindac (600 or $1,200 \mu \mathrm{M}$ ) or sulindac sulfide (100 or $175 \mu \mathrm{M}$ ) as described in Methods. Their ability to phosphorylate exogenously added histone $\mathrm{H} 1$ in vitro was determined using $\gamma-{ }^{32} \mathrm{P}$-ATP as the donor. Control reactions involved immunoprecipitation of the lysates using a nonspecific normal adult rabbit serum $(N L R)$. The specific reaction is indicated as $\alpha$-cdc2 (a) or $\alpha$-cdk2 (b). The products of the reaction were fractionated on $10 \%$ SDS-PAGE gels and visualized by autoradiography. Each band was cut out of dried gels and quantitated, as described in Methods, and the counts are indicated below each lane; all control reactions had counts $<0.4 \times 10^{3} \mathrm{cpm}$. The cell cycle phase distribution of these cells (bottom) was determined in an aliquot of these cells by FACS analysis, as described in Methods. The positions of molecular weight standards are depicted to the left of each panel.

relative incorporation of label, after $72 \mathrm{~h}$ of treatment with sulindac $1,200 \mu \mathrm{M}$ and sulindac sulfide $175 \mu \mathrm{M}$. Compared to control, the histone $\mathrm{H} 1$ kinase activity of $\mathrm{p} 34^{\mathrm{cdc} 2}$ and $\mathrm{p} 33^{\mathrm{cdk} 2}$ was reduced 93.4 and $95 \%$, respectively, by sulindac $1,200 \mu \mathrm{M}$ and 98.7 and $98.1 \%$, respectively, by sulindac sulfide $175 \mu \mathrm{M}$. These concentrations also reduced the proliferation and altered the morphology and cell cycle phase distribution of these cells (Fig. 9, bottom). There was no effect on the associated histone H1 kinase activity of $\mathrm{p} 34^{\text {cdc2 }}$ (Fig. $9 a$ ) or $\mathrm{p} 33^{\text {cdk2 }}$ (Fig. $9 b$ ) upon treatment with sulindac or sulindac sulfide at lower concentrations that had minimal, if any, effect on cdk levels on Western blot (Fig. 8) or on the cell cycle phase distribution of these cells (Fig. 9, bottom). To exclude the possibility that 


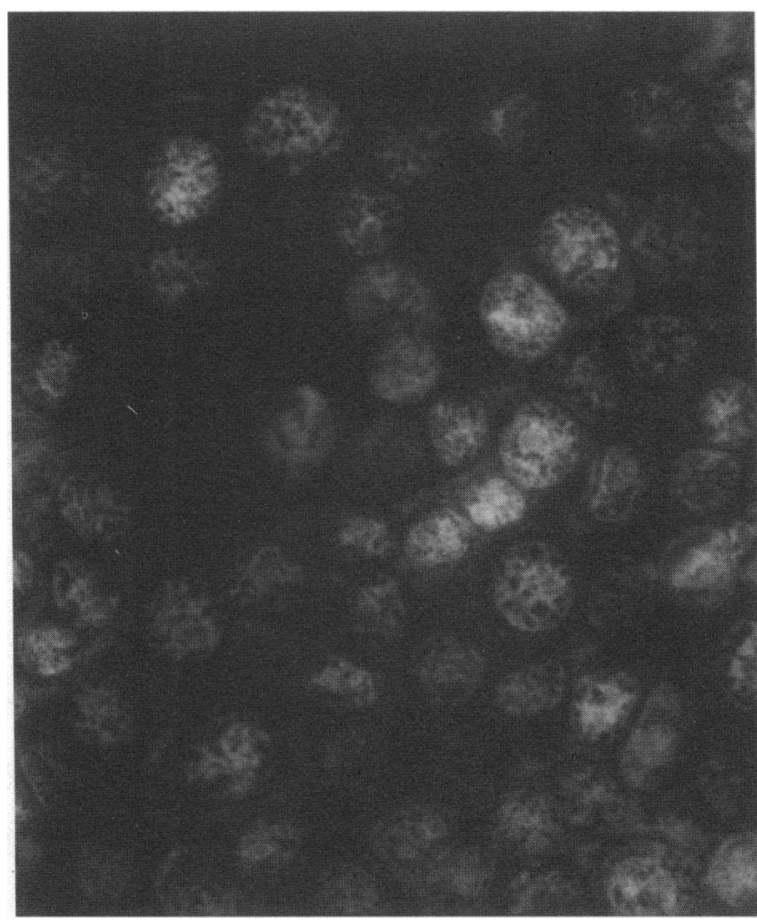

(a)

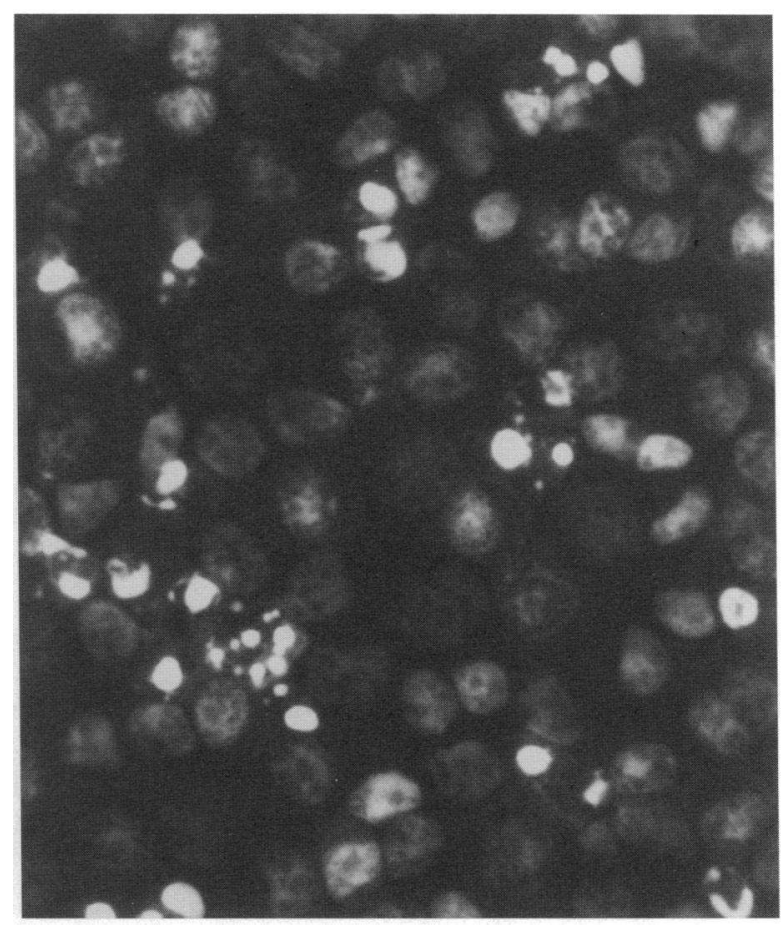

(b)

Figure 10. Fluorescence photomicrograph of HT-29 cells treated with sulindac sulfide. Control cells $(a)$ and those treated with sulindac sulfide (175 $\mu \mathrm{M})$ for $72 \mathrm{~h}(b)$ were stained with acridine orange and evaluated by UV fluorescent microscopy, as described in Methods. Changes in the cells typical of apoptosis: the presence of cytoplasmic and nuclear shrinkage; chromatin condensation; and cytoplasmic blebbing with maintenance of the integrity of the cell membrane (zeiosis) was seen in $(b) . \times 40$.

these compounds directly inhibit the catalytic activity of $\mathrm{p} 34^{\mathrm{cdc} 2}$ and $\mathrm{p} 33^{\text {cdk2 }}$, sulindac $(1,200 \mu \mathrm{M})$ and sulindac sulfide $(175$ $\mu \mathrm{M})$ were added to the $\mathrm{p} 34^{\mathrm{cdc} 2}$ and $\mathrm{p} 33^{\text {cdk2 }}$ IP-kinase assays from lysates of HT-29 cells incubated in control medium for $72 \mathrm{~h}$. There was no difference in the associated histone $\mathrm{H} 1$ kinase activity in these reactions compared to those without the compounds added to the kinase buffer (data not shown).

Hence, in a concentration-dependent manner, though nonlinear and restricted to the higher concentrations tested, sulindac and sulindac sulfide: $(a)$ induced a significant shift in the cell cycle phase distribution towards $\mathrm{G}_{0} / \mathrm{G}_{1}$; and $(b)$ reduced the levels of three critical cell cycle regulators, $\mathrm{p} 34^{\mathrm{cdc} 2}, \mathrm{p} 33^{\mathrm{cdk} 2}$, and $\mathrm{p} 34^{\text {cdk4 }}$ in HT-29 colon adenocarcinoma cells. Furthermore, the reduction in the levels of $\mathrm{p} 34^{\mathrm{cdc} 2}$ and $\mathrm{p} 33^{\mathrm{cdk} 2}$ was also accompanied by a reduction in their catalytic activity. On a molar basis, sulindac sulfide was six times more potent than sulindac in bringing about these effects. These data indicate that critical cell cycle transition points, $G_{1} \rightarrow S, G_{2} \rightarrow M$ and possibly the progression through $G_{1}$ were profoundly inhibited by treatment with these compounds. Given the known significance of inhibiting cdk function on cell cycle progression $(17,18)$, these results suggest that high concentrations of sulindac and sulindac sulfide increase the fraction of cells with $G_{0} / G_{1}$ DNA content by arresting them in the $G_{1}$ or $G_{0}$ phase of the cell cycle through an effect on the molecular components that regulate cell cycle transitions.

Sulindac sulfide induces apoptosis in HT-29 colon cancer cells and HL-60 promyelocytic leukemia cells

Treatment of HT-29 colon cancer cells with sulindac and sulindac sulfide reduced the net cell accumulation over time. Both compounds also arrested a substantial fraction of these cells in the $G_{0}$ or $G_{1}$ phase of the cell cycle. This phenomenon could explain, in part, the anti-proliferative effect of high concentrations of these compounds on cultured HT-29 cells. However, we suspected that the anti-proliferative effect of higher concentrations of sulindac sulfide, in particular, might be multifactorial because a large percentage of HT-29 cells treated with high concentrations of sulindac sulfide developed less than a diploid amount of DNA on FACS analysis (Fig. $7 b$ ). This sub-diploid peak in DNA content correlates with the morphologic and biochemical hallmarks of apoptosis $(43,44)$. Therefore, we sought to determine whether sulindac sulfide treatment induces apoptosis in HT-29 colon cancer cells.

HT-29 cells were treated with either control medium or sulindac sulfide- ( $100 \mu \mathrm{M}, 150 \mu \mathrm{M}$, or $200 \mu \mathrm{M})$ supplemented medium for $72 \mathrm{~h}$ after which their morphology was evaluated by acridine orange staining. Sulindac sulfide, at concentrations that altered the cell cycle distribution of these cells, induced morphological hallmarks of apoptosis. As is evident in Fig. 10, a high fraction of $175 \mu \mathrm{M}$ sulindac sulfide-treated cells exhibit nuclei with condensed and fragmented chromatin. In addition, the plasma membrane remained intact around these aberrant nuclei and, in some cells, the condensed DNA appeared to bud off from the remainder of the cell. Table II shows that after 72 $\mathrm{h}$ of sulindac sulfide $(\geq 150 \mu \mathrm{M})$ treatment, $15-26 \%$ of the cells developed apoptotic changes. Table II also demonstrates that this effect was concentration dependent. Sulindac also induced apoptosis in a concentration-dependent manner, but to a far lesser degree and at higher concentrations than sulindac sulfide (Table II). When treated with control medium, sulindac $600 \mu \mathrm{M}$, or sulindac sulfide $100 \mu \mathrm{M}, \mathrm{HT}-29$ cells did not exhibit 
Table II. Apoptosis in HT-29 Cells Treated with Sulindac or Sulindac Sulfide

\begin{tabular}{cc}
\hline \multicolumn{1}{c}{ Drug } & Percent apoptosis \\
\hline$\mu M$ & \\
Sulindac & \\
0 & 0 \\
600 & $0.6 \pm 0.2$ \\
1200 & $7.0 \pm 1.6$ \\
Sulindac sulfide & \\
0 & $0.4 \pm 0.2$ \\
100 & $0.1 \pm 0.1$ \\
150 & $15.2 \pm 2.4$ \\
175 & $15.5 \pm 0.5$ \\
200 & $26.1 \pm 3.2$ \\
\end{tabular}

The percentage of apoptosis, determined as described in Methods, after treatment with various concentrations of these compounds, is represented as the mean \pm SEM of at least three duplicate experiments.

appreciable levels of apoptosis. Thus apoptosis was prominent in sulindac- and sulindac sulfide-treated cells only at the higher concentration ranges which induced an effect on the cell cycle distribution of these cells.

The degradation of genomic DNA, another marker of apoptosis, was also analyzed to measure the apoptotic response of HT-29 cells to sulindac sulfide treatment. Fig. $11 a$ shows that treatment with $200 \mu \mathrm{M}$ sulindac sulfide resulted in degradation of the genomic DNA of these cells, leading to a conspicuous smear below the predominant genomic DNA band. The DNA smear pattern in HT-29 cells was correlated with greater amounts of apoptosis seen after acridine orange staining (Fig. 10 ) and with the height of the sub-diploid peak in DNA content noted on FACS analysis (Fig. 7 and data not shown). Fig. 11 $b$ also shows genomic DNA prepared in the same fashion from HL-60 cells treated for $4 \mathrm{~h}$ with either control medium or sulindac sulfide- (50-200 $\mu \mathrm{M}$ ) supplemented medium. The HL-60 cells developed a nucleosomal ladder pattern of DNA degradation, considered distinctive of apoptosis, on treatment with higher concentrations of sulindac sulfide. A characteristic ladder pattern was also observed in sulindac sulfide-treated HT- 29 cells when greater amounts of DNA were resolved on agarose gels (Fig. $11 c$ ).

Thus, sulindac sulfide induced apoptosis in HT-29 colon adenocarcinoma cells in three assays commonly used to demonstrate this phenomenon.

\section{Discussion}

Our findings demonstrate that the NSAIDs sulindac and sulindac sulfide have profound effects on HT-29 colon adenocarcinoma cells in vitro. These compounds reduce the proliferation rate of these cells, cause changes in their morphology, induce them to accumulate in the $G_{0} / G_{1}$ phase of the cell cycle, and induce cell death by apoptosis. These responses are time-dependent, reversible, and are prominent at the higher concentrations of sulindac and sulindac sulfide tested. The response of these cells to sulindac is not due to extensive conversion to sulindac sulfide in the culture medium during incubation with the HT29 cells.

Our findings that sulindac and sulindac sulfide have profound anti-proliferative effects on HT-29 colon adenocarcinoma cells are in agreement with previous studies demonstrating that many of the NSAIDs inhibit the proliferation of nonintestinal cultured cell lines $(11,12,31,48-51)$. For example, sulindac sulfide, one of the compounds we studied, inhibited the accumulation of lapine chondrocytes (51). Sulindac sulfide and, to a lesser degree, sulindac inhibit cyclooxygenase (prostaglandin synthetase) activity (52). However, whether inhibition of eicosanoid synthesis plays a role in the effect of sulindac or sulindac sulfide on cell proliferation remains unresolved $(12,53)$.

We also report that sulindac and sulindac sulfide cause a reversible change in the morphology of HT-29 cells. These morphological changes, long cytoplasmic extensions and intracytoplasmic vesicles, were similar to those reported by Neupert and Müller who treated rat embryo fibroblasts with indometha- (a)

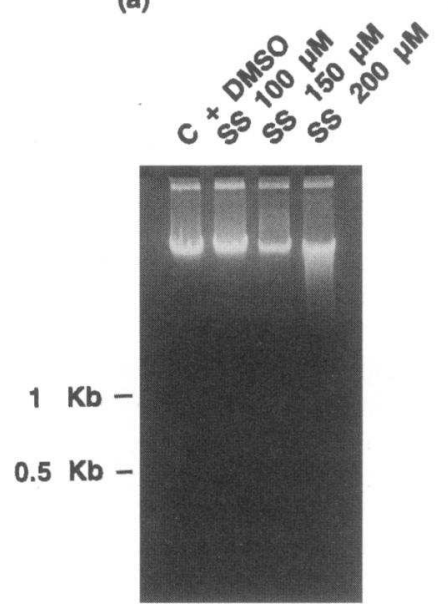

(b)
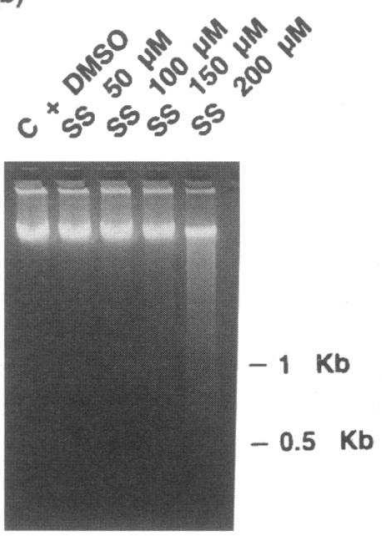

(c)

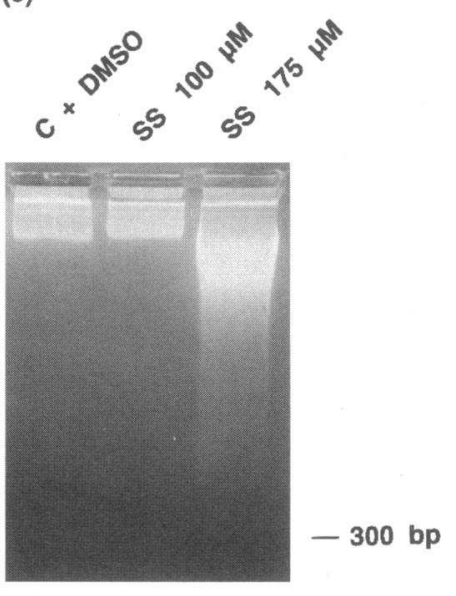

Figure 11. Electrophoresis of genomic DNA from HL-60 and HT29 cells treated with sulindac sulfide. Genomic DNA was isolated from HT-29 colon adenocarcinoma cells $(a)$ or HL-60 promyelocytic leukemia cells $(b)$, and fractionated on $1.8 \%$ agarose gels, as described in Methods. HT-29 cells treated with sulindac sulfide $200 \mu \mathrm{M}$ show a smear pattern which was not seen in control cells or those treated with sulindac sulfide $100 \mu \mathrm{M}$; cells treated with sulindac sulfide $150 \mu \mathrm{M}$ show a weak smear pattern $(a)$. The typical ladder pattern often associated with apoptosis was seen when genomic DNA was isolated by the

same method from HL-60 cells treated with increasing concentrations of sulindac sulfide $(b)$. A ladder pattern of DNA degradation was seen in DNA extracted from HT-29 cells treated with sulindac sulfide $175 \mu \mathrm{M}$ when $10 \mu \mathrm{g}$ of DNA was resolved on the agarose gels $(c$, lane 3$)$. The position of DNA molecular weight standards are shown to the side of each panel. The DNA in each lane of $a$ corresponds to $1 \times 10^{5}$ cells, whereas in $b$ it corresponds to $2 \times 10^{5}$ cells, in $c$ it corresponds to $10 \mu \mathrm{g}$. $C$, control; $S S$, sulindac sulfide. 
cin (48). It is noteworthy that, in our experiments, the morphological changes caused by sulindac and sulindac sulfide occurred over the concentration ranges which also reduced the proliferation of the HT-29 cells.

Our study demonstrates that, in addition to reducing the proliferation and altering morphology, sulindac and sulindac sulfide alter the cell cycle distribution of HT-29 cells. Sulindac and sulindac sulfide caused an increase in the proportion of cells in the $G_{0} / G_{1}$ phase and a decrease in the percentage of cells in the $S$ and $G_{2} / M$ phases. This effect was reversible and occurred at the higher end of the concentration range that altered cell morphology and inhibited cell proliferation. Previous studies on nonintestinal cells have described a similar cell cycle effect in response to indomethacin treatment $(11,12,31)$. In our work, the combination of cell type (colon) and class of NSAID (sulindac and sulindac sulfide) is important because of the striking human data that show the colon to be a key target for the action of these drugs (3-5).

The changes in the cell cycle phase distribution of HT-29 cells in response to sulindac and sulindac sulfide treatment, were accompanied by profound reductions in the level and activity of key proteins that regulate progression through the cell cycle. Sulindac and sulindac sulfide reduced the level of cdks ( $\mathrm{p} 34^{\mathrm{cdc} 2}$, $\mathrm{p} 33^{\text {cdk2 }}, \mathrm{p} 34^{\text {cdk4 }}$ ), and also the in vitro kinase activity of $\mathrm{p} 34^{\text {cdc2 }}$ and $\mathrm{p} 33^{\text {cdk2 }}$; we did not measure the in vitro kinase activity of p34 ${ }^{\text {cdk } 4}$ in this study. The relative deficiency in the activity of these key proteins may contribute to the accumulation of these cells in the $G_{0} / G_{1}$ phase following treatment with sulindac and sulindac sulfide. The reduced levels of these proteins may explain their reduced activity. However, the possibility that cdk inhibitors also play a role in this phenomenon has not yet been ruled out (15). The mechanisms through which these compounds influence the levels of these cdk proteins remains unknown. It is conceivable that exogenous sulindac and sulindac sulfide produce this effect by influencing signaling pathways in these cells that control the levels of these proteins. Regardless of the exact molecular mechanism involved, the reduction in the level and activity of certain cdks may be important for the anti-proliferative effect of these compounds.

Sulindac and, more potently, sulindac sulfide induce apoptosis in HT-29 colon adenocarcinoma cells. To our knowledge, this is the first report to document that a class of NSAIDs can induce cell death by apoptosis in colonic epithelial cells. Apoptosis in response to sulindac sulfide treatment was documented by showing the appearance of: $(a)$ morphological changes characteristic of apoptosis; $(b)$ a sub-diploid peak of DNA content on FACS analysis; and (c) genomic DNA degradation. Evidence that apoptosis was induced by sulindac was based on the detection of morphological changes only; no subdiploid peak was noted on DNA content frequency histograms. The apoptosis induced by these compounds likely also contributes to their effect on the growth rate of HT-29 cells. Furthermore, additional studies we have performed, which will be reported elsewhere, have shown that sulindac sulfide induces apoptosis in other colon cancer cell lines such as HCT-15 (54).

Under the influence of higher concentrations of sulindac and sulindac sulfide, the cell cycle distribution, the activity of cell cycle kinases and the rate of apoptosis all changed in parallel. These responses occurred at concentrations of sulindac above $600 \mu \mathrm{M}$ and of sulindac sulfide above $100 \mu \mathrm{M}$. However, the correlation between the effect of these compounds on cell proliferation and on these responses was not as strict at lower concentrations. For example, sulindac sulfide $100 \mu \mathrm{M}$ did not produce a robust effect on the cell cycle phase distribution, the level and activity of the cdks, or on apoptosis at $72 \mathrm{~h}$. Nevertheless, at this concentration, cell proliferation was inhibited by $42 \%$. Similar observations were made with sulindac. Proliferation, as is measured in our model system, is likely the result of a complex interplay between many factors such as apoptosis, cell cycle progression, and other responses. Our data cannot ascertain, with precision, the individual contribution of these factors to the final outcome, i.e., proliferation. The effect of these two compounds on HT-29 cell proliferation at lower concentrations remains unexplained. However, the clear-cut responses of these cells to higher concentrations at $72 \mathrm{~h}$ likely affect cell proliferation. Clearly, further investigation is required to fully explain the anti-proliferative effect at lower concentrations of sulindac and sulindac sulfide.

The ability of sulindac sulfide to induce apoptosis in tumor cells is not restricted to those derived from the colon. Sulindac sulfide also produced apoptosis in HL-60 promyelocytic leukemia cells, at concentrations similar to those that induced apoptosis in HT-29 cells. Unlike colon cells that showed a smear pattern when DNA was size fractionated on agarose gels, apoptosis in HL-60 cells was accompanied by a typical DNA ladder pattern. The reason for this difference is unclear. Since apoptosis is a genetically programmed process, our findings suggest that the cellular pathways responsible for sulindac sulfide-induced apoptosis are likely to be present in non-intestinal cells as well. Wild-type p53 protein is thought to be an important mediator of apoptosis, especially in response to DNA damage $(55,56)$. Since HL-60 cells lack p53 protein (57) and HT-29 cells do not contain wild-type p53 protein (58), the apoptosis induced by sulindac sulfide is likely independent of wild-type p53 protein.

It remains to be seen whether the results presented here, obtained from an in vitro tissue culture study, can be extrapolated to humans. In fact, such an extrapolation cannot be made based on our data. However, it is possible that the concentrations of sulindac sulfide used here can be reached in the colon in vivo. For example, humans given sulindac sulfide, at doses that regress polyps in FAP patients, achieve plasma concentrations of sulindac sulfide of $\sim 10-15 \mu \mathrm{M}(35,36)$. Pharmacological studies have demonstrated that colon tissue levels of sulindac sulfide far exceed those in plasma; tissue to plasma ratios in the colon are in the range of $10-20(33,34)$. In addition, since approximately half of the sulindac sulfide in plasma originates from sulindac via bacterial metabolism in the colon (32), high concentrations of this compound reaches colon cells through the lumen. As a result of this analysis through lumenal exposure and tissue accumulation, it is conceivable that high concentrations of sulindac sulfide, in the range that produced the cellular effects we observed in vitro, can be achieved in the colon of humans. Finally, since both compounds are highly protein bound (1), the effective concentration (or concentration of free molecules) in the culture dishes is really unknown.

Sulindac, in humans, reaches plasma levels of $\sim 10 \mu \mathrm{M}$ but, in contrast to sulindac sulfide, it does not accumulate in colonic tissue (34). Thus, it is less likely that sulindac achieves tissue levels comparable to those that were effective in this study $(1,200 \mu \mathrm{M})$. However, the possibility that high lumenal levels are reached in the microenvironment of the colonic crypts cannot be excluded. Overall, by virtue of its reported tissue accumulation and in vitro potency, sulindac sulfide appears the 
more likely of the two compounds responsible for the biological changes that have been observed with sulindac in vivo.

It is also conceivable that apoptosis might occur in the human colon in response to sulindac. There is limited histologic evidence that treatment with mefanamic acid and diclofenac can induce apoptosis in the human colon. Lee has shown induction of apoptosis in the crypts of colorectal biopsy specimens from patients who developed gastrointestinal symptoms in response to these NSAIDs (59). The apoptosis noticed in his study, uncharacteristically however, was associated with an inflammatory cell infiltration in the lamina propria and the crypts.

.Apoptosis in the gut mucosa may be relevant to the pathogenesis of gastrointestinal malignancies. Qualitative differences in apoptosis in the small intestine, as compared with that in the colon and rectum, may help to explain the disparate incidence rates of adenocarcinoma between these organs (60). Also of interest, sodium butyrate, a short-chain fatty acid generated in high concentrations in the colon by bacterial fermentation of dietary fiber (61) induced apoptosis in HT-29 cells (62). The inverse relationship between fruit and vegetable fiber intake in the diet and colorectal cancer is generally accepted (63). Whether apoptosis plays a role in this process is an interesting hypothesis, but at this time, there is no data to support it.

In summary, we conclude that the NSAIDs sulindac and sulindac sulfide have anti-proliferative effects on cultured HT29 colon cancer cells in vitro. Relatively high concentrations of sulindac and sulindac sulfide cause a reversible accumulation of cells in the $G_{0}$ or $G_{1}$ phase of the cell cycle that is accompanied by reduced levels and activity of certain cdks. In addition, similar concentrations of these compounds induce apoptosis in HT-29 cells. Sulindac sulfide is approximately six times more potent than sulindac in inducing these responses. The induction of apoptosis and cell cycle quiescence are both anti-proliferative responses that likely contribute to the inhibition of HT-29 cell proliferation observed when they are treated with high concentrations of these compounds. We speculate that these responses may also contribute to the cancer preventive and tumor regressive properties of sulindac in vivo.

\section{Acknowledgments}

The assistance of A. Hawxhurst in the preparation of this manuscript and the critical review and helpful suggestions of A. Pittas, D. Khanam, and Drs. F. Cross and J. Hirsch are greatly appreciated. We thank Dr. C. Kwan for helpful discussions on the pharmacology and metabolism of sulindac.

We also thank The Athena Cultural Foundation, Ms. A. Perroti, and The Clinical Scholars Fund at The Rockefeller University for financial support. Sulindac sulfide was a generous gift of Merck and Co.

\section{References}

1. Insel, P. 1990. Analgesic-antipyretics and antiinflammatory agents; drugs employed in the treatment of rheumatoid arthritis and gout. In Goodman and Gilman's The Pharmacological Basis of Therapeutics. A. G. Gilman, T. W. Rall, A. S. Nies, and P. Taylor, editors. Pergamon Press, New York. 638-681.

2. Gridley, G., J. McLaughlin, A. Ekbom, L. Klareskog, H. Adami, R. Hoover, and J. J. Fraumeni. 1993. Incidence of cancer among patients with rheumatoid arthritis. J. Natl. Cancer Inst. 85:307-310.

3. Giovannucci, E., E. B. Rimm, M. J. Stampfer, G. A. Colditz, A. Ascherio, and W. C. Willett. 1994. Aspirin use and the risk for colorectal cancer and adenoma in male health professionals. Ann. Intern. Med. 121:241-246.

4. Waddell, W. R., and R. W. Loughry. 1983. Sulindac for polyposis of the colon. J. Surg. Oncol. 24:83-87.

5. Giardiello, F. M., S. R. Hamilton, A. J. Krush, S. Piantadosi, L. M. Hylind,
P. Celano, S. V. Booker, C. R. Robinson, and G. J. Offerhaus. 1993. Treatment of colonic and rectal adenomas with sulindac in familial adenomatous polyposis. New Engl. J. Med. 328:1313-1316.

6. Thorson, A. G., H. T. Lynch, and T. C. Smyrk. 1994. Rectal cancer in FAP patient after sulindac. Lancet 343:180.

7. Reddy, B., C. Rao, A. Rivenson, and G. Kelloff. 1993. Inhibitory effect of aspirin on azoxymethane-induced colon carcinogenesis in F344 rats. Carcinogenesis (Oxf.). 14:1493-1497.

8. Moorghen, M., P. Ince, K. J. Finney, J. P. Sunter, D. R. Appleton, and A. J. Watson. 1988. A protective effect of sulindac against chemically-induced primary colonic tumours in mice. J. Pathol. 156:341-347.

9. Pollard, M., P. H. Luckert, and M. A. Schmidt. 1983. The suppressive effect of piroxicam on autochthonous intestinal tumors in the rat. Cancer Lett. 21:57-61.

10. Pollard, M., and P. H. Luckert. 1981. Effect of indomethacin on intestinal tumors induced in rats by the acetate derivative of dimethylnitrosamine. Science (Wash. DC). 214:558-559.

11. Bayer, B., H. Kruth, M. Vaughn, and M. Beaven. 1979. Arrest of cultured cells in the $\mathrm{G}_{1}$ phase of the cell cycle by indomethacin. J. Pharmacol. Exp. Ther. 210:106-111.

12. Bayer, G., and M. Beaven. 1979. Evidence that indomethacin reversibly inhibits cell growth in the $G_{1}$ phase of the cell cycle. Biochem. Pharmacol. 28:441-443.

13. Sherr, C. J. 1993. Mammalian $\mathrm{G}_{1}$ cyclins. Cell. 73:1059-1065.

14. Murray, A., and T. Hunt. 1993. The Cell Cycle: An Introduction. WH Freeman and Co., New York. 251 pp.

15. Pines, J. 1994. Arresting developments in cell-cycle control. Trends Biochem. Sci. 19:143-145.

16. Fang, F., and J. W. Newport. 1991. Evidence that the G1-S and G2-M transitions are controlled by different $\mathrm{cdc} 2$ proteins in higher eukaryotes. Cell. 66:731-742.

17. Riabowol, K., G. Draetta, L. Brizuela, D. Vandre, and D. Beach. 1989 The cdc2 kinase is a nuclear protein that is essential for mitosis in mammalian cells. Cell. 57:393-401.

18. Van den Heuvel, S., and E. Harlow. 1993. Distinct roles for cyclindependent kinases in cell cycle control. Science (Wash. DC). 262:2050-2054.

19. Pines, J., and T. Hunter. 1989. Isolation of a human cyclin cDNA: evidence for cyclin mRNA and protein regulation in the cell cycle and for interaction with p34cdc2. Cell. 58:833-846.

20. Tsai, L.-H., E. Lees, B. Faha, E. Harlow, and K. Riabowol. 1993. The cdk2 kinase is required for the G1-to-S transition in mammalian cells. Oncogene. 8:1593-1602.

21. Koff, A., A. Giordano, D. Desai, K. Yamashita, J. W. Harper, S. Elledge, T. Nishimoto, D. O. Morgan, B. R. Franza, and J. M. Roberts. 1992. Formation and activation of a cyclin E-cdk2 complex during the G1 phase of the human cell cycle. Science (Wash. DC). 257:1689-1694.

22. Dulic, V., E. Lees, and S. I. Reed. 1992. Association of human cyclin E with a periodic G1-S phase protein kinase. Science (Wash. DC). 257:1958-1961. 23. Ohtsubo, M., and J. M. Roberts. 1993. Cyclin-dependent regulation of G1 in mammalian fibroblasts. Science (Wash. DC). 259:1908-1912.

24. Resnitzky, D., M. Gossen, H. Bujard, and S. I. Reed. 1994. Acceleration of the $G_{1} / S$ phase transition by expression of cyclins $D 1$ and $E$ with an inducible system. Mol. Cell. Biol. 14:1669-1679.

25. Matsushime, H., M. E. Ewen, D. K. Strom, J. Y. Kato, S. K. Hanks, M. F. Roussel, and C. J. Sherr. 1992. Identification and properties of an atypical catalytic subunit (p34PSK-J3/cdk4) for mammalian D type G1 cyclins. Cell. 71:323-334.

26. Matsushime, H., D. E. Quelle, S. A. Shurtleff, M. Shibuya, C. J. Sherr, and J.-Y. Kato. 1994. D-type cyclin-dependent kinase activity in mammalian cells. Mol. Cell. Biol. 14:2066-2076.

27. Meyerson, M., and E. Harlow. 1994. Identification of $G_{1}$ kinase activity for cdk6, a novel cyclin D partner. Mol. Cell. Biol. 14:2077-2086.

28. Baldin, V., J. Lukas, M. J. Marcote, M. Pagano, and G. Draetta. 1993. Cyclin D1 is a protein required for cell cycle progression in G1. Genes \& Dev. 7:812-821.

29. Draetta, G., and D. Beach. 1988. Activation of cdc2 protein kinase during mitosis in human cells: cell cycle-dependent phosphorylation and subunit rearrangement. Cell. 54:17-26.

30. Rosenblatt, J., Y. Gu, and D. O. Morgan. 1992. Human cyclin-dependent kinase 2 is activated during the $\mathrm{S}$ and G2 phases of the cell cycle and associates with cyclin A. Proc. Natl. Acad. Sci. USA. 89:2824-2828.

31. Adolphe, M., G. Deysson, and P. Lechat. 1972. Action of some steroid and non-steroid anti-inflammatory agents on the cell cycle: cytophotometric study of the DNA content. Rev. Europ. Études. Clin. Biol. 17:320-323.

32. Strong, H. A., N. J. Warner, A. G. Renwick, and C. F. George. 1985. Sulindac metabolism: the importance of an intact colon. Clin. Pharmacol. Ther. 38:387-393.

33. Waddell, W. R., G. F. Ganser, E. J. Cerise, and R. W. Loughry. 1989. Sulindac for polyposis of the colon. Am. J. Surg. 157:175-179.

34. Duggan, D. E., K. F. Hooke, and S. S. Hwang. 1980. Kinetics of the 
tissue distributions of sulindac and metabolites: relevance to sites and rates of bioactivation. Drug Metab. Dispos. 8:241-246.

35. Swanson, B. N., V. K. Boppana, P. H. Vlasses, G. I. Holmes, K. Monsell and R. K. Ferguson. 1982. Sulindac disposition when given once and twice daily. Clin. Pharmacol. Ther. 32:397-403.

36. Duggan, D. E., L. E. Hare, C. A. Ditzler, B. W. Lei, and K. C. Kwan. 1977. The disposition of sulindac. Clin. Pharmacol. Ther. 21:326-335.

37. Cohen, J. J. 1993. Apoptosis. Immunol. Today 14:126-130.

38. Kerr, J. F. R., C. M. Winterford, and B. V. Harmon. 1994. Apoptosis: its significance in cancer and cancer therapy. Cancer (Phila.). 73:2013-2026.

39. Vaux, D. L., G. Haecker, and A. Strasser. 1994. An evolutionary perspective on apoptosis. Cell. 76:777-779.

40. Laemmli, U. K. 1970. Cleavage of structural proteins during the assembly of the head of bacteriophage T4. Nature (Lond.). 227:680-685.

41. Smith, P. K., R. I. Krohn, G. T. Hermanson, A. K. Mallia, F. H. Gartner, M. D. Provenzano, E. K. Fujimoto, N. M. Goeke, B. J. Olson, and D. C. Klenk. 1985. Measurement of protein using bicinchoninic acid. Anal. Biochem. 150:7685.

42. Harlow, E., and D. Lane. 1988. Antibodies: A Laboratory Manual. Cold Spring Harbor Laboratory, Cold Spring Harbor, NY. 726 pp.

43. Elstein, K. H., and R. M. Zucker. 1994. Comparison of cellular and nuclear flow cytometric techniques for discriminating apoptotic subpopulations. Exp. Cell Res. 211:322-331.

44. Darzynkiewicz, Z., S. Bruno, G. Del Bino, W. Gorczyca, M. A. Hotz, P. Lassota, and F. Traganos. 1992. Features of apoptotic cells measured by flow cytometry. Cytometry. 13:795-808.

45. Darzynkiewicz, Z. 1990. Differential staining of DNA and RNA in intact cells and isolated cell nuclei with acridine orange. Methods Cell Biol. 33:285298.

46. Wyllie, A. H. 1980. Glucocorticoid-induced thymocyte apoptosis is associated with endogenous endonuclease activation. Nature (Lond.). 284:555-556.

47. Tsai, L. H., E. Harlow, and M. Meyerson. 1991. Isolation of the human cdk2 gene that encodes the cyclin A- and adenovirus E1A-associated p33 kinase. Nature (Lond.). 353:174-177.

48. Neupert, G., and P. Müller. 1975. Growth inhibition and morphological changes caused by indomethacin in fibroblasts in vitro. Experimentelle Pathologie. 11:1-9.

49. Karzel, K., H. Aulepp, and G. Hack. 1973. Effects of recently developed antiphlogistic drugs on viability, reduplication, mean volume and volume distribution of mammalian cells cultured in vitro. Pharmacology (Basel). 10:272-290.
50. Hial, V., M. C. F. De Mello, Z. Horakova, and M. A. Beaven. 1977. Antiproliferative activity of anti-inflammatory drugs in two mammalian cell culture lines. J. Pharmacol. Exp. Ther. 202:446-454.

51. Kirkpatrick, C. J., W. Mohr, A. Mildfeuer, and O. Haferkamp. 1983. Influence of nonsteroidal anti-inflammatory agents on lapine articular chondrocyte growth in vitro. Zeitschrift für Rheumatologie 42:58-65.

52. Meade, E. A., W. L. Smith, and D. L. DeWitt. 1993. Differential inhibition of prostaglandin endoperoxide synthase (cyclooxygenase) isozymes by aspirin and other non-steroidal antiinflammatory drugs. J. Biol. Chem. 268:6610-6614.

53. Beaven, M. A., M. C. F. de Mello, V. Hial, and Z. Horakova. 1977. In vitro inhibition of cell proliferation by anti-inflammatory drugs. Fed. Proc 36:1037.

54. Hanif, R., J. Feng, M. I. Koutsos, L. Staiano-Coico, S. J. Shiff, and B. Rigas. 1995. NSAIDs inhibit the growth of colon cancer cells by a prostaglandinindependent pathway. Gastroenterology. 108:A553.

55. Lowe, S. W., E. M. Schmitt, S. W. Smith, B. A. Osborne, and T. Jacks. 1993. p53 is required for radiation-induced apoptosis in mouse thymocytes. Nature (Lond.). 362:847-849.

56. Lowe, S. W., H. E. Ruley, T. Jacks, and D. E. Housman. 1993. p53dependent apoptosis modulates the cytotoxicity of anticancer agents. Cell. 74:957-967.

57. Wolf, D., and V. Rotter. 1985. Major deletions in the gene encoding the p53 tumor antigen cause lack of p53 expression in HL-60 cells. Proc. Natl. Acad. Sci. USA. 82:790-794.

58. Rodrigues, N. R., A. Rowan, M. E. Smith, I. B. Kerr, W. F. Bodmer, J. V. Gannon, and D. P. Lane. 1990. p53 mutations in colorectal cancer. Proc. Natl. Acad. Sci. USA. 87:7555-7559.

59. Lee, F. D. 1993. Importance of apoptosis in the histopathology of drug related lesions in the large intestine. J. Clin. Pathol. 46:118-122.

60. Potten, C. S., Y. Q. Li, P. J. O'Connor, and D. J. Winton. 1992. A possible explanation for the differential cancer incidence in the intestine, based on distribution of the cytotoxic effects of carcinogens in the murine large bowel. Carcinogenesis. 13:2305-2312.

61. Cummings, J. H. 1981. Short chain fatty acids in the human colon. Gut. 22:763-779.

62. Hague, A., A. M. Manning, K. A. Hanlon, L. I. Huschtscha, D. Hart, and C. Paraskeva. 1993. Sodium butyrate induces apoptosis in human colonic tumour cell lines in a p53-independent pathway: implications for the possible role of dietary fibre in the prevention of large-bowel cancer. Int. J. Cancer 55:498-505.

63. Spiro, H., 1993. Clinical Gastroenterology. McGraw-Hill, NY. 798 pp. 